\title{
Toward a revision of the genus Synura, section Petersenianae (Synurophyceae, Heterokontophyta): morphological characterization of six pseudo-cryptic species
}

\author{
Pavel ŠKaloud $^{1 *}$, Anna Kynčlová ${ }^{1}$, Oldǒ̃ \\ ${ }^{1}$ Department of Botany, Faculty of Science, Charles University, Benátská 2, Prague 2, CZ-12801, Czech Republic \\ ${ }^{2}$ Institute of Microbiology, v.v.i., Academy of Sciences of the Czech Republic, Videňská 1083, Prague 4, CZ-14220, \\ Czech Republic
}

\begin{abstract}
ŠKaloud P., Kynčlová A., Benada O., Kofroňová O. And ŠKaloudová M. 2012. Toward a revision of the genus Synura, section Petersenianae (Synurophyceae, Heterokontophyta): morphological characterization of six pseudocryptic species. Phycologia 51: 303-329. DOI: 10.2216/11-20.1

Morphological data, based on transmission and scanning electron microscopy of silica scales, are provided for six genetic lineages of the Synura petersenii species complex as revealed by multiple genetic markers (internal transcribed spacer rDNA, $p s a \mathrm{~A}, r b c \mathrm{~L}$ and $c o x 1)$. The morphology allows clear distinction of all six lineages, as well as their separation from all other taxa in section Petersenianae. The lineages are redefined or described as new species in accordance with previously published molecular and morphometric evidence as S. petersenii, S. glabra, S. truttae comb. et stat. nov., S. americana sp. nov., S. macropora sp. nov. and $S$. conopea sp. nov. The section Petersenianae further includes nine taxa with well-known ultrastructural characteristics. Four have status of species $(S$. australiensis, $S$. longisquama, $S$. macracantha and $S$. obesa), and five have been described as different formae of $S$. petersenii sensu lato ( $S$. petersenii f. asmundiae, S. petersenii f. bjoerkii, S. petersenii f. columnata, S. petersenii f. praefracta and S. petersenii f. taymyrensis). All 15 taxa can be distinguished by the shape of the body scales, scale dimensions, keel shape, number of and distance between struts, degree of interconnections between struts, and the size of base plate pores, keel pores, and base plate hole. A key to species is provided. The biogeography of newly defined taxa is discussed based on the morphological data obtained from previously published reports.
\end{abstract}

Key Words: Cryptic species, Silica scales, Synura petersenii, Taxonomy

\section{INTRODUCTION}

Synura Ehrenberg is a genus of colony-forming organisms in which a variable number of cells are joined together at their posterior ends. Each cell is covered by imbricate silica scales, whose ultrastructure essentially defines the particular species. Several scale types occur on the same cell, depending on their position. Apart from the prevailing body scales, apical and rear scales can also be observed and are characterized by their different length to width ratios. The body scales are thought to be the most important for correct species determination because they exhibit the most highly developed characters (Kristiansen \& Preisig 2007). However, the transitions between body, apical, and rear scales are gradual rather than sudden.

In 1974, the genus Synura was split into three sections: Synura, Petersenianae and Lapponicae (Balonov \& Kuzmin 1974), following the previously proposed splitting by Petersen \& Hansen (1956). The section Petersenianae was defined as having body scales with a central keel that may end in a spine-like projection. Within the section, the identification of species and subspecific taxa is primarily based upon scale dimensions, keel shape, base plate hole size or on the presence and number of struts (ribs) and their interconnections. Presently, the section Petersenianae includes five species: Synura australiensis Playfair, $S$.

\footnotetext{
*Corresponding author(skaloud@natur.cuni.cz).
}

longisquama Wujek \& Elsner, S. macracantha (Petersen \& Hansen) Asmund, $S$. obesa Němcová, Nováková \& Řezáčová-Škaloudová and $S$. petersenii Korshikov (Kristiansen \& Preisig 2007; Němcová et al. 2008). Moreover, several subspecific taxa within $S$. petersenii have been described on the basis of variations in scale morphology. However, the taxonomic status and morphological delineation of several $S$. petersenii forms remains ambiguous. For example, the $S$. petersenii f. glabra (Korshikov) Kristiansen \& Preisig morphotype was first described by Korshikov (1929) as a new species, Synura glabra Korshikov. In the same paper, Korshikov described Synura petersenii. The main difference between these two species is the scale shape and the presence or absence of struts, which are well developed in $S$. petersenii and much reduced or absent in S. glabra. In 1941 Huber-Pestalozzi united the two species under the name $S$. petersenii, and morphotype glabra was ranked as a variety; later, it was given the status of forma (Kristiansen \& Preisig 2007).

In our recent study (Kynčlová et al. 2010), we discovered that six different clades can be unambiguously distinguished within the Synura petersenii species on the basis of several independent approaches, including molecular analysis of the internal transcribed spacer (ITS) rRNA region, identification of compensatory base changes (CBCs) and hemi-CBCs, and a morphological analysis comprising both geometric morphometrics and traditional morphometric methods. The results were extraordinarily congruent, providing robust evidence for the presence of cryptic 
Table 1. Specific names, strain numbers, geographic origin and GenBank accession numbers of analyzed strains. Strains used for morphological comparisons are given in bold.

\begin{tabular}{|c|c|c|c|c|c|c|}
\hline \multirow[b]{2}{*}{ Taxon } & \multirow[b]{2}{*}{ Strain } & \multirow[b]{2}{*}{ Locality } & \multicolumn{4}{|c|}{ GenBank accession numbers } \\
\hline & & & ITS & $p s a \mathrm{~A}$ & $r b c \mathrm{~L}$ & $\operatorname{cox} 1$ \\
\hline Symura americana & CCMP 854 & pool below spillway, Island Lake, IL, USA & GU338120 & GU325169 & GU325481 & GU295525 \\
\hline S. americana & CCMP 861 & Winter's Creek, Keeweenaw County, MI, USA & GU338123 & GU325172 & GU325484 & GU295528 \\
\hline S. americana & CCMP 862 & Winter's Creek, Keeweenaw County, MI & GU338124 & GU325173 & GU325485 & GU295529 \\
\hline S. americana & CCMP 863 & $\begin{array}{l}\text { road ditch near Winter's Creek, Keeweenaw } \\
\text { County, MI, USA }\end{array}$ & GU338125 & GU325174 & GU325486 & GU295530 \\
\hline S. americana & CСMP 866 & Newfoundland, Canada & AF308840 & - & - & - \\
\hline S. americana & Sandgren \#2 & North America & GU338130 & GU325179 & GU325491 & - \\
\hline S. americana & UTEX LB 2404 & Sportsman's Lake, San Juan Island, WA, USA & GU338132 & GU325183 & GU325495 & GU295538 \\
\hline S. americana & UTCC 495 & Newfoundland Hwy 410, Newfoundland, Canada & - & GU325185 & GU325497 & GU295540 \\
\hline S. conopea & S 7.10 & Babín pool, Ždárské vrchy PLA, Czech Republic & FM178506 & - & - & - \\
\hline S. conopea & S 10.2 & $\begin{array}{l}\text { Huťský pond, Novohradské hory, South Bohemia, } \\
\text { Czech Republic }\end{array}$ & FM178507 & - & - & - \\
\hline S. conopea & S 17.2 & Babín pool, Ždárské vrchy PLA, Czech Republic & FR819746 & - & - & - \\
\hline S. conopea & S 29.3 & Kladský pond, West Bohemia, Czech Republic & FR819745 & - & - & - \\
\hline S. conopea & CCMP 859 & southeast bridge pond, Washington County, AR, USA & GU338121 & GU325170 & GU325482 & GU295526 \\
\hline S. conopea & NIES 1007 & Tomakomai, Hokkaido, Japan & GU338119 & GU325168 & GU325479 & GU295524 \\
\hline S. conopea & KNU13 & Dalseonggyo, Gyeongju, Korea & GU338069 & GU325116 & GU325430 & GU295472 \\
\hline S. glabra & S 8.1 & Kyjský pond, Prague, Czech Republic & FM178511 & - & - & - \\
\hline S. glabra & S 9.1 & confluence of the Morava and Dyje rivers, Czech Republic & FM178512 & - & - & - \\
\hline S. glabra & S 9.2 & confluence of the Morava and Dyje rivers, Czech Republic & FM178513 & - & - & - \\
\hline S. glabra & S 14.1 & peatbog, Swamp NR, North Bohemia, Czech Republic & FM178514 & - & - & - \\
\hline S. glabra & S 26.1 & $\begin{array}{l}\text { Huťský pond, Novohradské hory, South Bohemia, } \\
\text { Czech Republic }\end{array}$ & FR819747 & - & - & - \\
\hline S. glabra & S 32.2 & alluvial pool, Modřany, Prague, Czech Republic & FR819748 & - & - & - \\
\hline S. glabra & NIES 233 & Higashiyata River, Ibaraki, Japan & GU338118 & GU325167 & GU325480 & GU295523 \\
\hline S. glabra & CNU09 & Jiokji pond, Haman, Korea & GU338077 & GU325124 & GU325438 & GU295480 \\
\hline S. glabra & KNU10 & Bomun reservoir, Gyeongju, Korea & GU338066 & GU325113 & GU325427 & GU295469 \\
\hline S. macropora & S 5.1 & alluvial pool, Modřany, Prague, Czech Republic & FM178494 & - & - & - \\
\hline S. macropora & S 5.2 & alluvial pool, Modřany, Prague, Czech Republic & FM178495 & - & - & - \\
\hline S. macropora & S 5.3 & alluvial pool, Modřany, Prague, Czech Republic & FM178496 & - & - & - \\
\hline S. macropora & S 14.2 & peatbog, Swamp NR, North Bohemia, Czech Republic & FM178497 & - & - & - \\
\hline S. petersenii & S 1.1 & Zlatá stoka canal, Třeboň, Czech Republic & FM178498 & - & - & - \\
\hline S. petersenii & S 1.2 & Zlatá stoka canal, Třeboň, Czech Republic & FM178499 & - & - & - \\
\hline S. petersenii & S 1.3 & Zlatá stoka canal, Třeboň, Czech Republic & FM178500 & - & - & - \\
\hline S. petersenii & S 4.19 & Kladský pond, West Bohemia, Czech Republic & FM178503 & - & - & - \\
\hline S. petersenii & S 6.4 & $\begin{array}{l}\text { alluvial pool, Horní Lužnice NR, South Bohemia, } \\
\text { Czech Republic }\end{array}$ & FM178501 & - & - & - \\
\hline S. petersenii & S 6.5 & $\begin{array}{l}\text { alluvial pool, Horní Lužnice NR, South Bohemia, } \\
\text { Czech Republic }\end{array}$ & FM178502 & - & - & - \\
\hline S. petersenii & S 7.7 & Babín pool, Žď́rské vrchy PLA, Czech Republic & FM17 & - & - & - \\
\hline S. petersenii & S 16.2 & Xerr pond, South Bohemia, Czech Republic & FM178505 & - & - & - \\
\hline S. petersenii & SAG 120.79 & Lüneburger Heide, Meadow pool, Germany & GU338144 & GU325194 & GU325506 & GU295546 \\
\hline S. petersenii & CCMP 864 & road ditch, 6.3 miles north of Gay, MI, USA & GU338126 & GU325175 & GU325487 & GU295531 \\
\hline S. petersenii & CCMP 873 & Bluff Lake, Lake County, IL, USA & GU338129 & GU325178 & GU325490 & GU295534 \\
\hline S. petersenii & CNU06 & Wollyang, Naju, Korea & GU338074 & GU325121 & GU325435 & GU295477 \\
\hline S. truttae & S 15.3 & $\begin{array}{l}\text { peatbog, Úpské rašeliniště, Krkonoše NP, Czech } \\
\text { Republic }\end{array}$ & FM178508 & - & - & - \\
\hline S. truttae & S 15.5 & $\begin{array}{l}\text { peatbog, Úpské rašeliniště, Krkonoše NP, Czech } \\
\text { Republic }\end{array}$ & FM178509 & - & - & - \\
\hline S. truttae & S 15.9 & peatbog, Úpské rašeliniště, Krkonoše NP, Czech Republic & FM178510 & - & - & - \\
\hline S. truttae & S 34.1 & $\begin{array}{l}\text { forest pool near Mezní Louka, České Švýcarsko, } \\
\text { Czech Republic }\end{array}$ & FR819749 & - & - & - \\
\hline Synura sp. & And 2555 & roadside ditch, Keeweenaw County, MI, USA & 3845 & - & — & - \\
\hline Synura sp. & UTEX LB 239 & unknown & GU338135 & GU325181 & GU325493 & GU295536 \\
\hline Synura sp. & KNU01 & Uksu reservoir, Daegu, Korea & GU338057 & GU325105 & GU325418 & GU295460 \\
\hline Synura sp. & CCMP 2898 & Wallersee, Austria & GU338136 & GU325186 & GU325498 & - \\
\hline Synura sp. & CCAC 0052 & Cologne, Germany & GU338146 & GU325196 & GU325508 & GU295548 \\
\hline Synura sp. & CCMP 869 & Tobacco River, Keeweenaw County, MI, USA & GU338128 & GU325177 & GU325489 & GU295533 \\
\hline Synura sp. & CNU12 & Geomuyeokri, Yeongduk, Korea & GU338080 & GU325127 & GU325441 & GU295483 \\
\hline Synura sp. & CNU47 & Seongdong pond, Yeonggwang, Korea & GU338114 & GU325162 & GU325475 & GU295518 \\
\hline Synura sp. & CNU01 & Samhwa pond, Gwangju, Korea & GU338070 & GU338070 & GU325431 & GU295473 \\
\hline Synura sp. & CNU02 & Ojeong pond, Naju, Korea & GU338071 & GU338071 & GU325432 & GU295474 \\
\hline Synura sp. & CNU03 & Jeongsan, Cheongyang, Korea & GU338072 & GU325119 & GU325433 & GU295475 \\
\hline Synura sp. & CNU10 & Bihaksan, Pohang, Korea & GU338078 & GU325125 & GU325439 & GU295481 \\
\hline
\end{tabular}




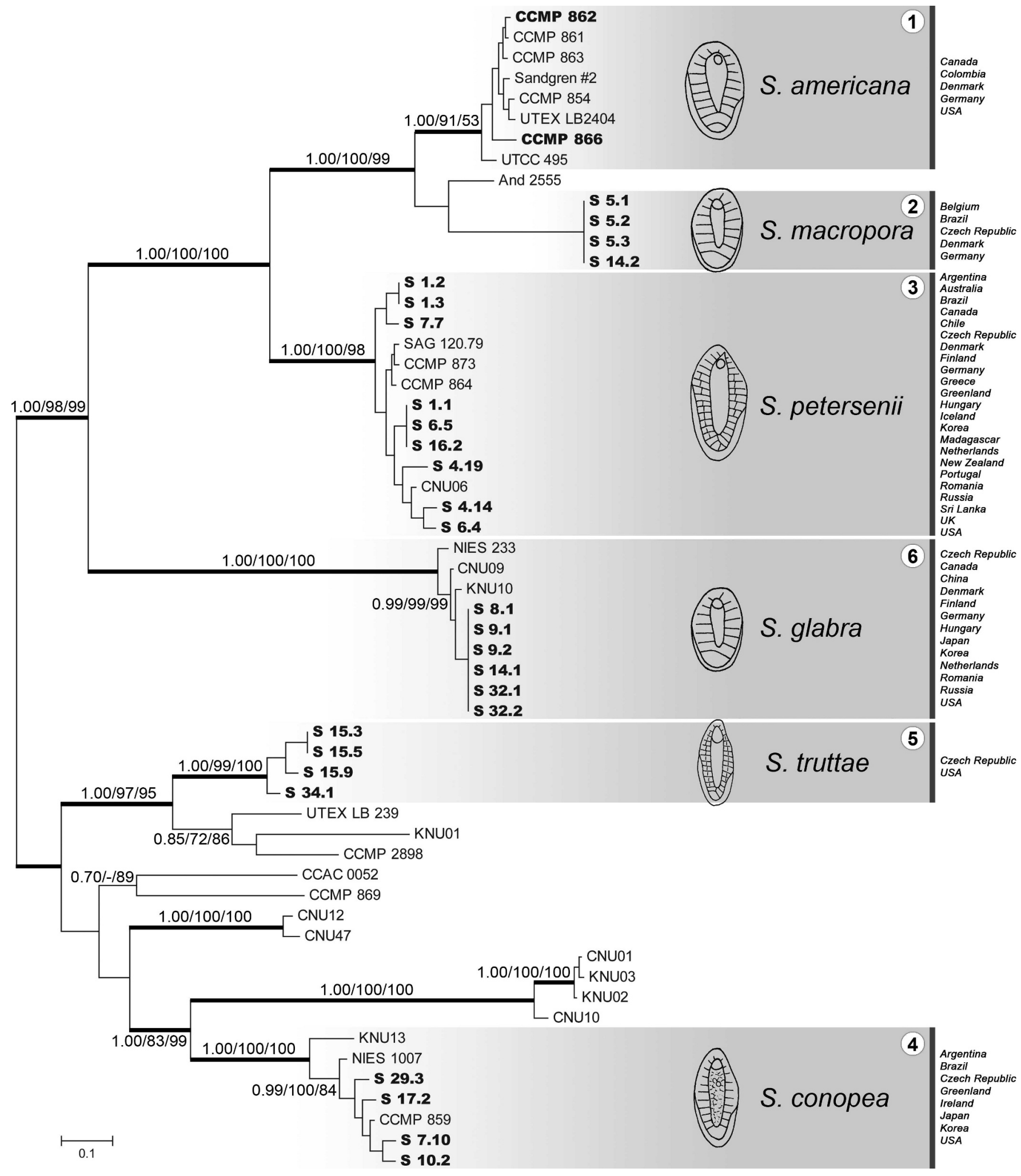

Fig. 1. Unrooted BI analysis based on the combined ITS rDNA, $p s a \mathrm{~A}, r b c \mathrm{~L}$ and $c o x 1$ dataset using a JC model for 5.8S ribosomal locus; HKY model for second codon positions of $p s a \mathrm{~A}$ and $r b c \mathrm{~L}$ genes; GTR+I model for first codon positions of $p s a \mathrm{~A}$ and $r b c \mathrm{~L}$ genes, and first and second codon positions of cox 1 gene; GTR+G model for internal transcribed spacers ITS1 and ITS2; and GTR $+\mathrm{I}+\mathrm{G}$ model for third codon positions of $p s a \mathrm{~A}, r b c \mathrm{~L}$ and $\operatorname{cox} 1$ genes. Values at the nodes indicate statistical support estimated by three methods - MrBayes posterior node probability (left), maximum likelihood bootstrap (middle) and maximum parsimony bootstrap (right). Only statistical supports higher than $0.70 / 70 / 70$ are shown. Thick branches highlight nodes receiving the highest PP support (1.00). Strains used for the morphological investigations are given in bold. Clade numbering follows Kynčlová et al. 2010. Scale bar = expected number of substitutions per site. 

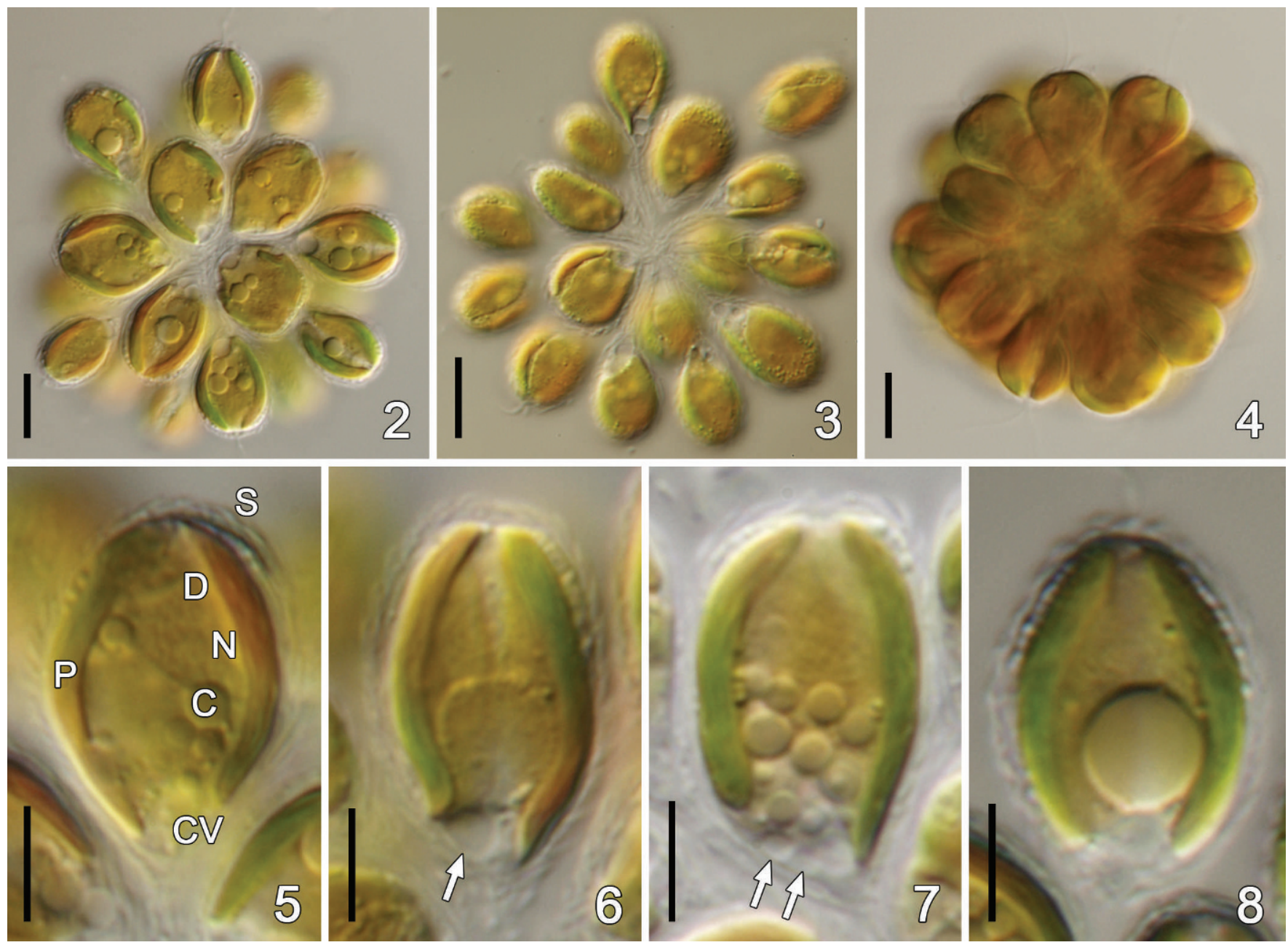

Figs 2-8. Light micrographs of Synura species. Scale bars represent $10 \mu \mathrm{m}$ (Figs 2-4) or $5 \mu \mathrm{m}$ (Figs 5-8).

Fig. 2. 24-celled colony (strain S 7.7).

Fig. 3. Colony. Note the long colourless cytoplasmic stalks attaching individual cells (S 7.7).

Fig. 4. Compact colony formed by densely grouped cells (S 32.1).

Fig. 5. Morphology of Synura cell (S 7.7); $\mathrm{C}=$ chrysolaminaran vacuole; $\mathrm{CV}=$ contractile vacuoles; $\mathrm{D}=$ dictyosome; $\mathrm{N}=$ nucleus; $\mathrm{P}=$ plastid; $\mathrm{S}=$ silica scales covering the cell.

Figs 6-8. Development of chrysolaminaran vacuoles (see text). Arrows indicate the contractile vacuoles (S 7.7).

Figs 9-20. Morphology of silica scales (Figs 9-16: TEM, Figs 17-20: SEM). Scale bars represent $1 \mu \mathrm{m}$ (Figs 9-16, 19-20) or $2 \mu \mathrm{m}$ (Figs 1718).

Fig. 9. General morphology of silica scale ( $\mathrm{S} 7.7) ; \mathrm{B}=$ basal plate; $\mathrm{H}=$ base plate hole; $\mathrm{K}=\mathrm{keel} ; \mathrm{KT}=\mathrm{keel}$ tip; $\mathrm{R}=\mathrm{rim}$; $\mathrm{S}=$ struts; $\mathrm{TF}=$ transverse folds. The arrowheads indicate the distant end of the membrane covering the keel pores (see SEM pictures).

Fig. 10. Lateral view of the scale (S 7.7); for abbreviations see Fig. 9.

Fig. 11. Body scale (S 7.7).

Fig. 12. Apical scale. Note distinct, rounded keel tip (S 7.7).

Fig. 13. Rear scale (S 7.7).

Fig. 14. Morphological differentiation of body and rear scales. The latter are marked by an asterisk (CCMP 862).

Fig. 15. Highly silicified scale, with number of transverse folds (S 7.7).

Fig. 16. Less silicified scale (S 7.7).

Fig. 17. Cell covered by oblong scales (CCMP 862).

Fig. 18. Cell covered by lanceolate scales (S 15.3).

Fig. 19. Single body scale with raised keel. Note distinct keel pores at the sides of the keel (CCMP 862).

Fig. 20. Body scales showing keel covered by number of small knobs (S 15.3). 

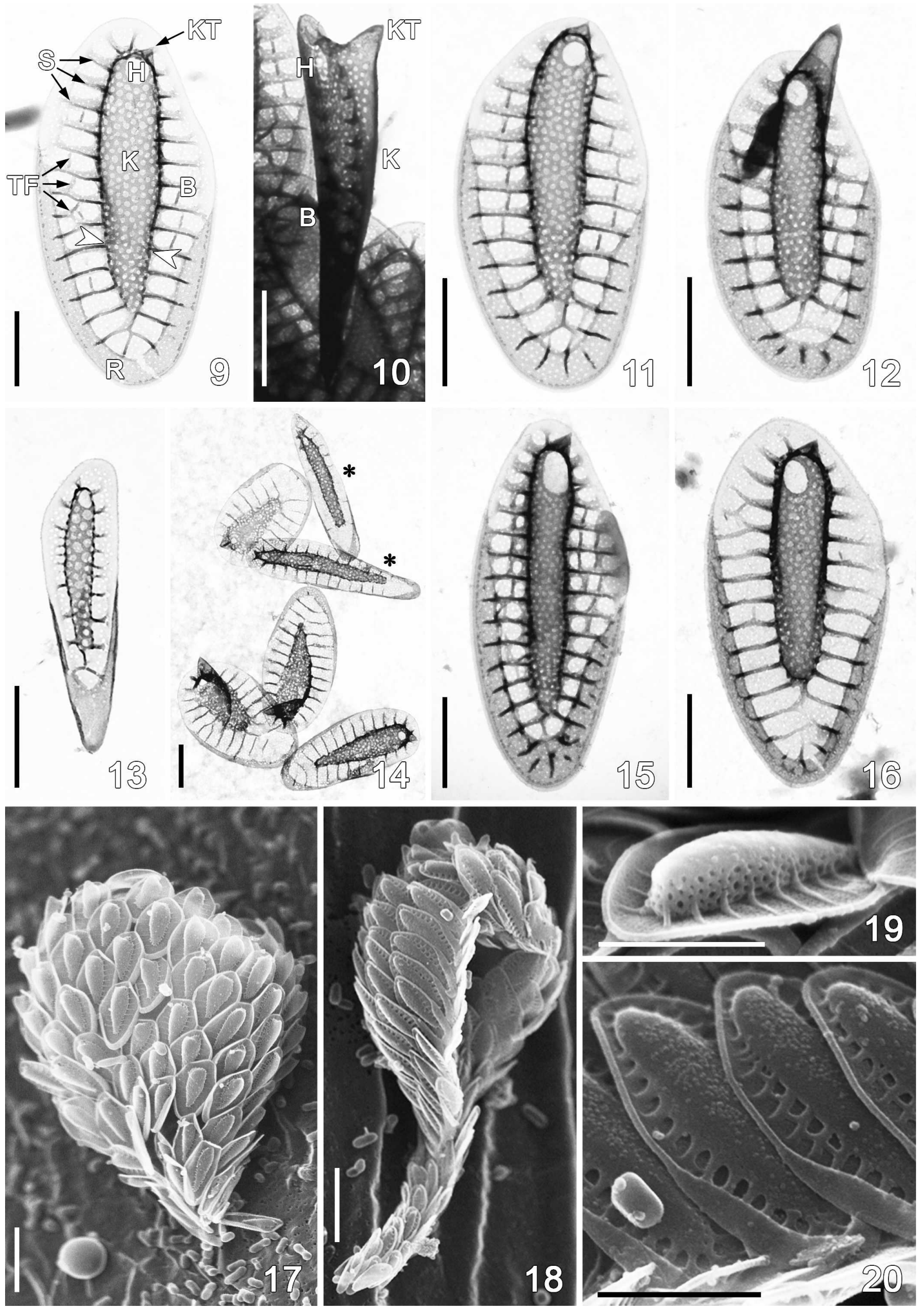
species within the $S$. petersenii morphotype. Similarly, the recent multigene phylogeny of a high number of $S$. petersenii s.l. isolates presented by Boo et al. (2010) confirmed the high degree of cryptic, species-level diversity within this nominal species.

Although both of the recent, above-mentioned studies substantiated the existence of several cryptic species in $S$. petersenii, morphological differences among the six clades investigated by Kynčlová et al. (2010) could be considered rather insignificant when compared with differences among the existing Synura forms and species. Therefore, in this study we provide more detailed data on the morphological differences among the clades in order to establish the basis for their unambiguous designation as separate, pseudocryptic species. Morphology of colonies and ultrastructure of silica scales were observed by light microscopy (LM), as well as by transmission (TEM) and scanning electron (SEM) microscopy. A multigene phylogenetic analysis was performed to better infer the phylogenetic position of investigated cryptic species.

\section{MATERIAL AND METHODS}

\section{Algal cultures and their morphological investigations}

The origins of all strains used in this study are provided in Table 1. For the morphological investigations, we used both our own isolates (designated as $\mathrm{S}$ ) and strains from the Provasoli-Guillard National Center for Culture of Marine Phytoplankton in Maine, USA (designated as CCMP). The isolation and cultivation of Synura strains, as well as their preparation for TEM, were described in Kynčlová et al. (2010). Light microscopic observations were based on cells grown in DY IV medium (Andersen et al. 1997). All cultures were maintained at $15^{\circ} \mathrm{C}$. Individual strains were observed using an Olympus BX51 light microscope. For SEM, approximately $1 \mathrm{ml}$ of each culture was fixed in buffered glutaraldehyde (3\% in $10 \mathrm{mM}$ phosphate buffer, $\mathrm{pH}$ 7.2) overnight. Fixed samples were washed three times with phosphate buffer, concentrated to a final volume of $40 \mu \mathrm{l}$ and allowed to sediment onto $0.2-\mu \mathrm{m}$ poly-L-lysine treated SPI-pore filters (SPI supplies, West Chester, PA, USA). The samples were then dehydrated through an alcohol series $(25 \%, 50 \%, 75 \%, 80 \%, 90 \%, 96 \%$ and $100 \%)$ followed by absolute acetone, and dried in a Balzers CPD010 critical-point drier (Balzers Instruments, Balzers, Liechtenstein). Finally, the samples were sputter-coated with gold in a Polaron sputter-coater (series 11HD) and examined in a Philips CM12/STEM electron microscope (FEI Company, Hillsboro, USA, formerly Philips EO, The Netherlands) at $80 \mathrm{kV}$ and spot size 7. Digital images were recorded using EDAX slow scan generator (AMETEK Inc, Paoli, PA, USA).

\section{Sequence alignment and phylogenetic analyses}

ITS rDNA sequences of 28 strains used for morphological investigations were acquired from GenBank or obtained by PCR amplifications and sequencing as described in Kynčlová et al. (2010). Sequences were aligned on the basis of their rRNA secondary structure information (Kynčlová et al. 2010) with MEGA 4 (Kumar et al. 2008). To better infer the phylogenetic relationship of investigated strains, sequences of ITS rDNA and the three additional organelle markers ( $p s a \mathrm{~A}, r b c \mathrm{~L}$ and $\operatorname{cox} 1$ ) of several other $S$. petersenii s.1. strains originated from the study of Boo et al. (2010) were acquired from GenBank (Table 1). The four loci were concatenated, yielding an alignment of 2973 bases. The phylogenetic tree was inferred with Bayesian inference (BI) using MrBayes version 3.1 (Ronquist \& Huelsenbeck 2003). The most appropriate substitution model was estimated for 12 partitions within the alignment using the Akaike Information Criterion (AIC) with PAUP/MrModeltest 1.0b (Nylander 2004). The five following substitution models were estimated: (1) JC for 5.8S ribosomal locus; (2) HKY for second codon positions of $p s a \mathrm{~A}$ and $r b c \mathrm{~L}$ genes; (3) $\mathrm{GTR}+\mathrm{I}$ for first codon positions of $p s a \mathrm{~A}$ and $r b c \mathrm{~L}$ genes, and first and second codon positions of $\operatorname{cox} 1$ gene; (4) $\mathrm{GTR}+\mathrm{G}$ for internal transcribed spacers ITS1 and ITS2; and (5) $\mathrm{GTR}+\mathrm{I}+\mathrm{G}$ for third codon positions of $p s a \mathrm{~A}, r b c \mathrm{~L}$ and $\operatorname{cox} 1$ genes. In the BI analysis, two parallel Markov chain Monte Carlo runs were carried out for 5 million generations, each with one cold and three heated chains. The dataset was divided into five partitions, for which different substitution models were selected according to the above-mentioned AIC-based model selection. Trees and parameters were sampled every 100 generations. Convergence of the two cold chains was checked and burn-in was determined using the 'sump' command.

Bootstrap analyses were performed by maximum likelihood (ML) and weighted parsimony (wMP) criteria using GARLI, version 0.951 (Zwickl 2006) and PAUP*, version 4.0b10 (Swofford 2002), respectively. ML analyses consisted of rapid heuristic searches (100 pseudo-replicates) using automatic termination (genthreshfortopoterm command set to 100,000$)$. The wMP bootstrapping (1000 replications) was performed using heuristic searches with 100 random sequence addition replicates, tree bisection reconnection swapping, random addition of sequences (the number limited to 10,000 for each replicate), and gap characters treated as a fifth character state.

\section{RESULTS}

\section{Phylogenetic analysis}

The concatenated (ITS rDNA, $p s a \mathrm{~A}, r b c \mathrm{~L}$ and $c o x 1$ ) Bayesian phylogeny (Fig. 1) revealed similar clustering of $S$. petersenii s.l. clones as presented by Kynčlová et al. (2010). All investigated clones clustered into six wellresolved clades (clade numbering follows Kynčlová et al. 2010): (1) CCMP 862 and CCMP 866; (2) S 5.1, S 5.2, S 5.3, and S 14.2; (3) S 1.1, S 1.2, S 1.3, S 4.14, S 4.19, S 6.4, S 6.5, S 7.7, and S 16.2; (4) S 7.10, S 10.2, S 17.2, and S 29.3; (5) S 15.3, S 15.5, S 15.9, and S 34.1; and (6) S 8.1, S 9.1, S 9.2, S 14.1, S 32.1 and $S$ 32.2. In the phylogenetic tree, two major, well-supported lineages were resolved. The first clade comprised clades 1, 2, 3 and 6 and clone And 2555, while the second lineage was composed of clades 4 and 5 , in addition to a number of lineages mostly represented by 


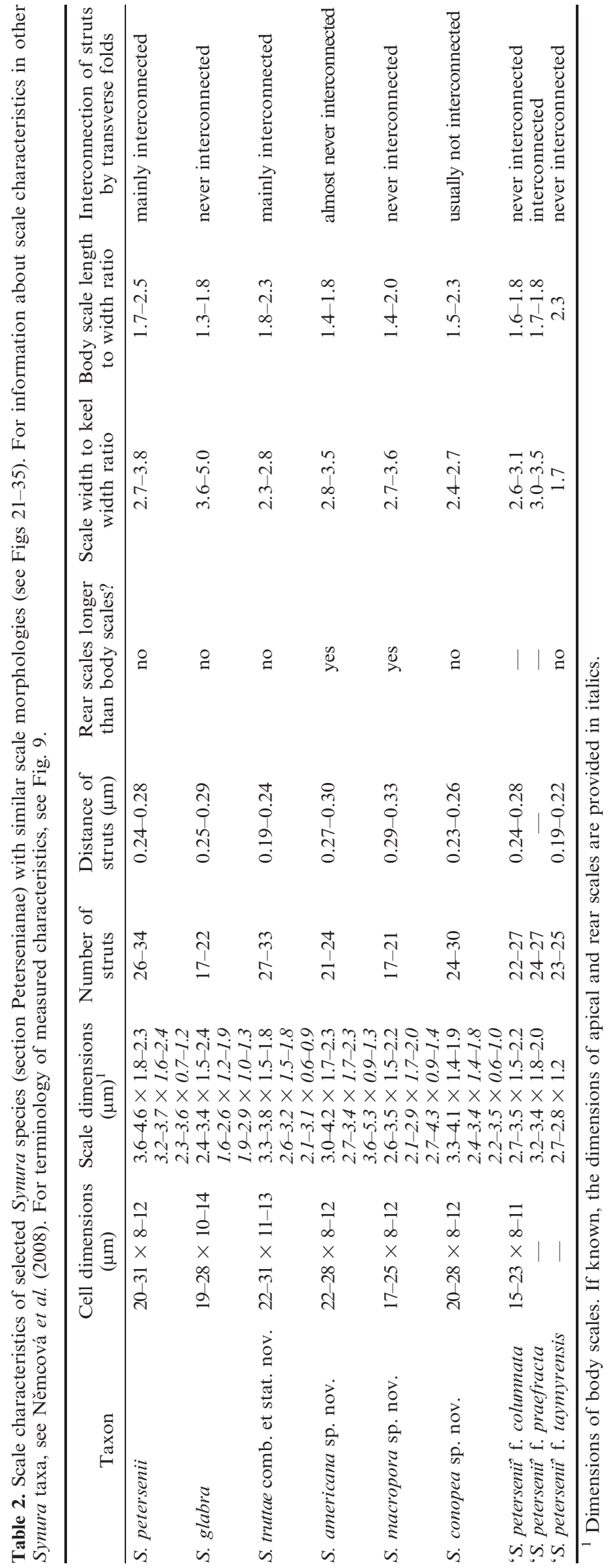




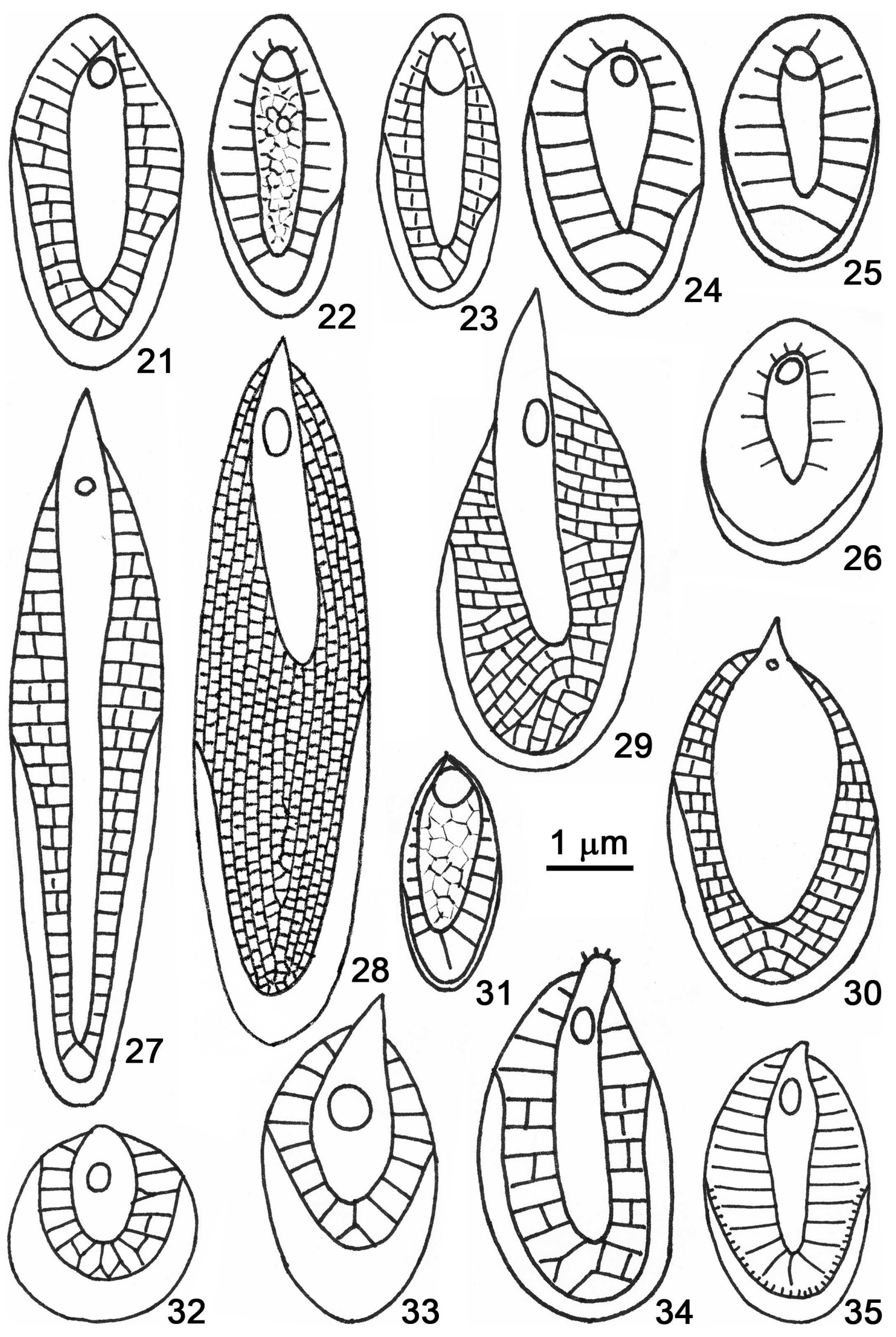


single clones (e.g. UTEX LB 239, KNU01, CCMP 2898, CCAC 0052).

\section{Light microscopy}

All investigated clones formed colonies that were identical in size and structure and generally undistinguishable from each other. The form, size and general structure of individual cells were also very similar. The colonies consisted of 2-24 golden-brown cells (Fig. 2). Each monad was pear-shaped to spherical and was attached to other members of the colony by a colourless, inwardly directed cytoplasmic stalk (Fig. 3). In clade 6, the cells in colonies were grouped very densely, and stalks were barely observable (Fig. 4). The range of cell dimensions was similar in all investigated clones. The cell length varied from 17 to $31 \mu \mathrm{m}$. The largest cells were found in clades 3 and 5 (20-31 and 22-31 $\mu \mathrm{m}$, respectively), and the shortest in clade $2(17-25 \mu \mathrm{m})$. Cell width was the same for most clades $(8-12 \mu \mathrm{m})$, exceptions being clades 5 and 6 with slightly broader cells (11-13 and 10-14 $\mu \mathrm{m}$, respectively). Two long flagella emerged from the broad end of the cell. Each cell possessed two parietal, golden-brown to pale green chloroplasts that extended the length of the cell excluding the stalk (Figs 2, 5). A spherical to oval nucleus with indistinct nucleolus was situated in the apical part of the cell. The large spindle-shaped dictyosome was located beneath the flagellar bases near the surface of the nucleus (Fig. 5). One to several chrysolaminaran vacuoles were located in the middle of the cell, their number depending on the age of the culture (Figs 6-8). Thus in young cells, a large number of minute chrysolaminaran vacuoles was observed (Fig. 6). Along with the ageing process, they increased in size (Fig. 7), merged and finally gave rise to a single large, centrally located vacuole (Fig. 8). In all clones, several contractile vacuoles were located in the posterior part of the cells (Figs 6, 7). They were inconsistent in position and number, as described by Korshikov (1929). The silica scales, forming a translucent case around the cells, were visible in all clones (Fig. 5). However, in clade 6, the cells appeared smooth, and only under the highest magnification could the fine silica case be observed.

\section{Transmission electron microscopy}

The scales of all the six lineages exhibited the characteristics typical of Synura section Petersenianae. The scales have a keel and a number of struts that extend regularly from the keel to the edge of the scale (Figs 9, 10). Generally, three scale types were identified in each strain; although, transitional morphologies between the three types were observed. Body scales (Fig. 11), usually with a central keel protruding into a short and acute keel tip, represented the most frequent scale type. The apical scales (Fig. 12) were smaller and more rounded. An elongated, more or less rounded keel tip was characteristic of this scale type. Rear scales (Fig. 13) were much narrower, and in two lineages (clades 1 and 2) longer (Fig. 14). Two different shapes of body scales were observed: lanceolate (clades 3, 4 and 5; scale length to width varying from 1.5 to $2.5 \mu \mathrm{m}$ ) and rounded (clades 1, 2 and 6; scale length to width varying from 1.3 to $2.0 \mu \mathrm{m}$ ). Struts were either simple without interconnections or interconnected by more or less developed transverse folds. In many strains, scales with highly connected struts and others lacking transverse folds were observed in the same culture (Figs 15, 16). Despite this, lineages with frequently interconnected struts (clades 3 and 5) or predominantly unconnected struts (clades 1 and 4) and those with simple struts lacking all interconnections (clades 2 and 6) could be identified.

From our investigation of 28 cultured strains, we were able to unambiguously distinguish and define six lineages using morphological features. In addition to the abovementioned morphological differences, the lineages could be distinguished by scale size, length to width ratio, ratio of scale and keel width, the number of and distance between struts, and the size of the base plate pores, keel pores and the base plate hole. The central morphological characteristics of these six lineages, as well as the other members of section Petersenianae, are presented in Table 2.

\section{Scanning electron microscopy}

The morphology of the scales as imaged by SEM corroborate the proposed differences among the lineages distinguished by TEM investigations. However, SEM

$\leftarrow$

Figs 21-35. Scale morphology of particular Synura species in section Petersenianae, shown in the same scale.

Fig. 21. S. petersenii.

Fig. 22. $S$. conopea sp. nov.

Fig. 23. $S$. truttae comb. et stat. nov.

Fig. 24. $S$. americana sp. nov.

Fig. 25. S. macropora sp. nov.

Fig. 26. S. glabra.

Fig. 27. S. australiensis.

Fig. 28. S. longisquama.

Fig. 29. S. macracantha.

Fig. 30. S. obesa.

Fig. 31. 'S. petersenii' f. taymyrensis.

Fig. 32. 'S. petersenii' f. asmundiae.

Fig. 33. 'S. petersenii' f. bjoerkii.

Fig. 34. 'S. petersenii' f. praefracta.

Fig. 35. 'S. petersenii' f. columnata. 
Table 3. Alphabetical check-list of all previously described species of the genus Synura. Species belonging to section Petersenianae are given in bold.

\begin{tabular}{|c|c|c|}
\hline Taxon & Section & Currently accepted? \\
\hline S. adamsii Smith 1924 emend. Nygaard 1949 & Petersenianae (according to Smith 1924) & yes \\
\hline S. adamsii f. malabarica Philipose 1953 & Petersenianae (according to Philipose 1953) & yes \\
\hline $\begin{array}{l}\text { S. australiensis Playfair } 1915 \text { emend. } \\
\text { Croome \& Tyler } 1985\end{array}$ & Petersenianae (Kristiansen \& Preisig 2007) & yes \\
\hline S. bioretii Huber-Pestalozzi 1941 & Synura (Kristiansen \& Preisig 2007) & $\begin{array}{l}\text { yes (probably }=S . \text { sphagnicola or } S . \\
\text { curtispina; Nicholls \& Gerrath } 1985 \text { ) }\end{array}$ \\
\hline S. biseriata Balonov 1976 & Synura (Kristiansen \& Preisig 2007) & yes \\
\hline S. caroliniana Whitford 1943 & Petersenianae (according to Whitford 1943) & yes \\
\hline S. conradii Kufferath in Conrad 1946 & Synura (Kristiansen \& Preisig 2007) & no $(=S$. echinulata $;$ Petersen \& Hansen 1958$)$ \\
\hline $\begin{array}{l}\text { S. curtispina (Petersen \& Hansen 1956) } \\
\text { Asmund } 1968\end{array}$ & Synura (Kristiansen \& Preisig 2007) & yes \\
\hline S. curtispina f. reticulata Asmund 1968 & Synura (Kristiansen \& Preisig 2007) & no $(=S$. curtispina $;$ Kristiansen \& Lind 1995$)$ \\
\hline S. danubiensis (Schiller 1929) Starmach 1968 & & $\begin{array}{l}\text { no }(=\text { Synuropsis danubiensis; Wujek \& } \\
\text { Thompson 2001) }\end{array}$ \\
\hline S. echinulata Korshikov 1929 & Synura (Kristiansen \& Preisig 2007) & yes \\
\hline S. echinulata f. leptorrhabda Asmund 1968 & Synura (Kristiansen \& Preisig 2007) & $\begin{array}{l}\text { no }(=S . \text { leptorrhabda; Nicholls in Nicholls \& } \\
\text { Gerrath 1985) }\end{array}$ \\
\hline S. elipidosa Skvortsov 1961 & Petersenianae (according to Skvortsov 1961) & yes \\
\hline S. falcata Skvortsov 1961 & Synura (according to Skvortsov 1961) & yes \\
\hline S. favus Bradley 1964 & Synura (Kristiansen \& Preisig 2007) & no $(=S$. curtispina $;$ Kristiansen \& Lind 1995$)$ \\
\hline S. glabra Korshikov 1929 & Petersenianae (Kristiansen \& Preisig 2007) & yes (this study) \\
\hline S. globosa (Schiller 1929) Starmach 1968 & Synura (Petersen \& Hansen 1956) & yes \\
\hline S. granulosa Playfair 1915 & Synura (according to Playfair 1915) & yes \\
\hline S. granulosa var. pusilla Playfair 1915 & Synura (according to Playfair 1915) & yes \\
\hline S. hyalina Skvortsov 1958 & - & no (nomen nudum - no description) \\
\hline S. hyalina var. aculeata Skvortsov 1958 & - & no (nomen nudum - no description) \\
\hline S. hyalina var. rotundata Skvortsov 1958 & - & no (nomen nudum - no description) \\
\hline $\begin{array}{l}\text { S. intermedia Bioret ex Kufferath in } \\
\text { Conrad } 1946\end{array}$ & Petersenianae (according to Conrad 1946) & yes \\
\hline $\begin{array}{l}\text { S. klebsiana (O. Zacharias 1897) } \\
\text { Lemmermann } 1899\end{array}$ & - & $\begin{array}{l}\text { no (= Chrysosphaerella sp.; Kristiansen \& } \\
\text { Preisig 2007) }\end{array}$ \\
\hline S. lapponica Skuja 1956 & Lapponica (Kristiansen \& Preisig 2007) & yes \\
\hline $\begin{array}{l}\text { S. leptorrhabda (Asmund 1986) Nicholls } \\
\text { in Nicholls \& Gerrath } 1985\end{array}$ & Synura (Kristiansen \& Preisig 2007) & yes \\
\hline S. lohammarii Skuja 1956 & Synura (Kristiansen \& Preisig 2007) & no $(=$ S. splendida; Péterfi 1967) \\
\hline S. longisquama Wujek \& Elsner 2000 & Petersenianae (Kristiansen \& Preisig 2007) & yes \\
\hline $\begin{array}{l}\text { S. macracantha (Petersen \& Hansen 1958) } \\
\text { Asmund } 1968\end{array}$ & Petersenianae (Kristiansen \& Preisig 2007) & yes \\
\hline S. mammillosa Takahashi 1972 & Synura (Kristiansen \& Preisig 2007) & yes \\
\hline S. microcrepis Nygaard 1978 & & $\begin{array}{l}\text { no }(=\text { Chrysodidymus synuroideus } \\
\text { Kristiansen \& Preisig 2007) }\end{array}$ \\
\hline $\begin{array}{l}\text { S. mollispina (Petersen \& Hansen 1956) } \\
\text { Péterfi \& Momeu } 1977\end{array}$ & Synura (Kristiansen \& Preisig 2007) & yes \\
\hline $\begin{array}{l}\text { S. multidentata (Balonov \& Kuzmin 1974) } \\
\text { Péterfi \& Momeu } 1977\end{array}$ & Synura (Kristiansen \& Preisig 2007) & yes \\
\hline $\begin{array}{l}\text { S. nygaardii (Petersen \& Hansen 1956) } \\
\text { Kristiansen et al. } 1997\end{array}$ & Synura (Kristiansen \& Preisig 2007) & yes \\
\hline S. petersenii Korshikov 1929 & Petersenianae (Kristiansen \& Preisig 2007) & yes \\
\hline $\begin{array}{l}\text { S. petersenii f. asmundiae Cronberg \& } \\
\text { Kristiansen } 1980\end{array}$ & Petersenianae (Kristiansen \& Preisig 2007) & yes \\
\hline $\begin{array}{l}\text { S. petersenii f. bjoerkii Cronberg \& } \\
\text { Kristiansen } 1980\end{array}$ & Petersenianae (Kristiansen \& Preisig 2007) & yes \\
\hline S. petersenii f. bonaerensis Vigna 1979 & Petersenianae (Kristiansen \& Preisig 2007) & no $(=\mathrm{S}$. petersenii; this study) \\
\hline S. petersenii f. columnata Siver 1988 & Petersenianae (Kristiansen \& Preisig 2007) & yes \\
\hline S. petersenii f. glabra & Petersenianae (Kristiansen \& Preisig 2007) & no (= S. glabra; this study) \\
\hline $\begin{array}{l}\text { S. petersenii f. kufferathii Petersen } \\
\text { \& Hansen } 1958\end{array}$ & Petersenianae (Kristiansen \& Preisig 2007) & no $(=\mathrm{S}$. petersenii; this study) \\
\hline $\begin{array}{l}\text { S. petersenii f. macracantha Petersen } \\
\text { \& Hansen } 1958\end{array}$ & Petersenianae (Kristiansen \& Preisig 2007) & no $(=$ S. macracantha; Asmund 1968) \\
\hline S. petersenii f. praefracta Asmund 1968 & Petersenianae (Kristiansen \& Preisig 2007) & yes \\
\hline $\begin{array}{l}\text { S. petersenii f. taymyrensis Kristiansen } \\
\text { et al. } 1997\end{array}$ & Petersenianae (Kristiansen \& Preisig 2007) & yes \\
\hline S. petersenii f. truttae Siver 1987 & Petersenianae (Kristiansen \& Preisig 2007) & no $(=S$. truttae; this study $)$ \\
\hline S. petersenii var. glabra & Petersenianae (Kristiansen \& Preisig 2007) & no $(=$ S. glabra; this study $)$ \\
\hline S. punctulosa Balonov 1976 & Synura (Kristiansen \& Preisig 2007) & yes \\
\hline S. recurvata Siver \& Wolfe 2005 & Synura (Siver \& Wolfe 2005) & yes (fossil species) \\
\hline S. reticulata Lemmermann 1904 & Synura (according to Fott \& Ludvík 1957) & no $(=S$. uvella $;$ Fott \& Ludvík 1957) \\
\hline $\begin{array}{l}\text { S. reticulata var. minor Chodat, Raineri } \\
\text { \& Drew } 1926\end{array}$ & Synura (according to Chodat et al. 1926) & yes \\
\hline
\end{tabular}


Table 3. Continued

\begin{tabular}{|c|c|c|}
\hline Taxon & Section & Currently accepted? \\
\hline S. reticulata var. verrucosa Pascher 1909 & Synura (according to Fott \& Ludvík 1957) & no $(=S$. uvella $;$ Fott \& Ludvík 1957) \\
\hline S. rotundata Skvortsov 1958 & & no (nomen nudum - no description) \\
\hline $\begin{array}{l}\text { S. sphagnicola (Korshikov 1927) } \\
\text { Korshikov } 1929\end{array}$ & Synura (Kristiansen \& Preisig 2007) & yes \\
\hline S. spinosa Korshikov 1929 & Synura (Kristiansen \& Preisig 2007) & yes \\
\hline $\begin{array}{l}\text { S. spinosa f. curtispina Petersen } \\
\text { \& Hansen } 1956\end{array}$ & Synura (Kristiansen \& Preisig 2007) & no $(=S$. curtispina $;$ Asmund 1968$)$ \\
\hline $\begin{array}{l}\text { S. spinosa } \mathrm{f} \text {. longispina } \text { Petersen } \\
\text { \& Hansen } 1956\end{array}$ & Synura (Kristiansen \& Preisig 2007) & yes \\
\hline $\begin{array}{l}\text { S. spinosa } \mathrm{f} \text {. mollispina } \text { Petersen } \\
\text { \& Hansen } 1956\end{array}$ & Synura (Kristiansen \& Preisig 2007) & no $(=$ S. mollispina $;$ Péterfi \& Momeu 1977) \\
\hline $\begin{array}{l}\text { S. spinosa f. nygaardii Petersen } \\
\text { \& Hansen } 1956\end{array}$ & Synura (Kristiansen \& Preisig 2007) & no $(=S$. nygaardii $;$ Kristiansen et al. 1997$)$ \\
\hline S. spinosa var. striata Cronberg 1989 & Synura (Kristiansen \& Preisig 2007) & yes \\
\hline S. splendida Korshikov 1942 & Synura (Kristiansen \& Preisig 2007) & yes \\
\hline $\begin{array}{l}\text { S. urogleniformis (Kisselev 1931) } \\
\text { Starmach } 1968\end{array}$ & & $\begin{array}{l}\text { no }(=\text { Synuropsis danubiensis; Wujek \& } \\
\text { Thompson 2001) }\end{array}$ \\
\hline $\begin{array}{l}\text { S. uvella Ehrenberg } 1834 \text { emend. } \\
\text { Korshikov } 1929\end{array}$ & Synura (Kristiansen \& Preisig 2007) & yes \\
\hline S. uvella $\mathrm{f}$. turfacea Steinecke 1916 & Synura (Kristiansen \& Preisig 2007) & no $(=S$. sphagnicola $;$ Fott \& Ludvík 1957$)$ \\
\hline S. uvella f. turfosa Steinecke 1922 & & no (nomen nudum - no description) \\
\hline S. uvella f. typica Pascher 1910 & Synura (Kristiansen \& Preisig 2007) & no $(=S$. uvella $;$ Korshikov 1929$)$ \\
\hline S. uvella var. longipes Vireux 1916 & Synura (Vireux 1916) & yes \\
\hline S. uvella var. punctata Averintsev 1901 & Synura (Kristiansen \& Preisig 2007) & no $(=S$. sphagnicola $;$ Fott \& Ludvík 1957) \\
\hline $\begin{array}{l}\text { S. uvella var. reticulata (Lemmermann 1904) } \\
\text { Pascher } 1910\end{array}$ & Synura (according to Fott \& Ludvík 1957) & no $(=S$. uvella $;$ Fott \& Ludvík 1957) \\
\hline S. uvella var. tiszaensis Kiss 1978 & Synura (Kristiansen \& Preisig 2007) & yes \\
\hline S. verrucosa Pascher 1913 & Synura (according to Fott \& Ludvík 1957) & no $(=S$. uvella $;$ Fott \& Ludvík 1957) \\
\hline S. virescens (Bory 1824) Playfair 1921 & Petersenianae (according to Playfair 1921) & yes \\
\hline
\end{tabular}

examination made it possible to visualize the various scale types on the cell surface (Figs 17, 18). The main difference between the SEM and TEM images is the visualization of the keel. In all clades, the keel was covered with a membrane hiding the pores of the keel (Fig. 17). The presence and range of this membrane was visible in TEM images as a slightly darker part of the keel (Fig. 9). In SEM images, the keel pores were visible only in the posterior portion of the keel and along the sides of the keel (Fig. 19). The keel was covered with a number of small knobs, especially in clade 5 (Fig. 20).

\section{DISCUSSION}

\section{Taxonomic revision of $S$. petersenii complex}

Based on the above-mentioned morphological characteristics, the differences between the six lineages is striking, although the morphology of some taxa might be judged somewhat similar. However, each lineage can be clearly defined by a combination of several morphological features (Table 2). The evidence presented in our recent study (Kynčlová et al. 2010) led us to the opinion that these six lineages represent pseudo-cryptic species within $S$. petersenii sensu lato. This conclusion is supported by morphological data, and the descriptions of several new species are herein proposed. However, prior to formal descriptions we need to (1) identify $S$. petersenii sensu stricto, (2) check for the identity of any lineage among previously described species and (3) delimit the newly defined species from all described taxa in section Petersenianae.
Synura petersenii was described by Korshikov (1929) based on material collected near Kharkov, Ukraine. It was named in honour of J.B. Petersen, who had described its scale structure under the name S. uvella (Petersen 1918). Korshikov's descriptions are very detailed, and he provided valuable information on the shape and dimensions of the silica scales. Electron micrographs of $S$. petersenii were first published by Petersen \& Hansen (1956), based on material collected in a Danish pond since there was no possibility of observing the original material on which $S$. petersenii was described. In his description of $S$. petersenii, Korshikov (1929) stated the length and width of the scales to be $4 \mu \mathrm{m}$ and $2 \mu \mathrm{m}$, respectively. These values agree with the observations made by Petersen \& Hansen (1956): length 3.6- $4.7 \mu \mathrm{m}$ and breadth $2.2-2.5 \mu \mathrm{m}$, with the body scale dimensions we determined for clade 3 (length $3.8-4.6 \mu \mathrm{m}$, breadth 1.8-2.3 $\mu \mathrm{m})$. All other aspects of scale morphology presented by Petersen \& Hansen (1956) also agree with our observations of clade 3 (e.g. overall scale shape, number and connections of struts; Fig. 21). We therefore do not hesitate to assign $S$. petersenii sensu stricto to clade 3 (Fig. 1).

We propose $S$. petersenii f. kufferathii Petersen \& Hansen and $S$. petersenii f. bonaerensis Vigna as synonyms of $S$. petersenii. The first form was distinguished from the type by a short central keel and interconnected struts (Petersen \& Hansen 1958). However, in the iconotype (plate V) the short keel was present on a single scale only. The most prominent feature of $S$. petersenii f. kufferathii, the interconnected struts, we frequently observed in the scales of $S$. petersenii (Figs 11, 12, 15). Moreover, scale dimensions and shape, as well as all other scale characteristics, are 

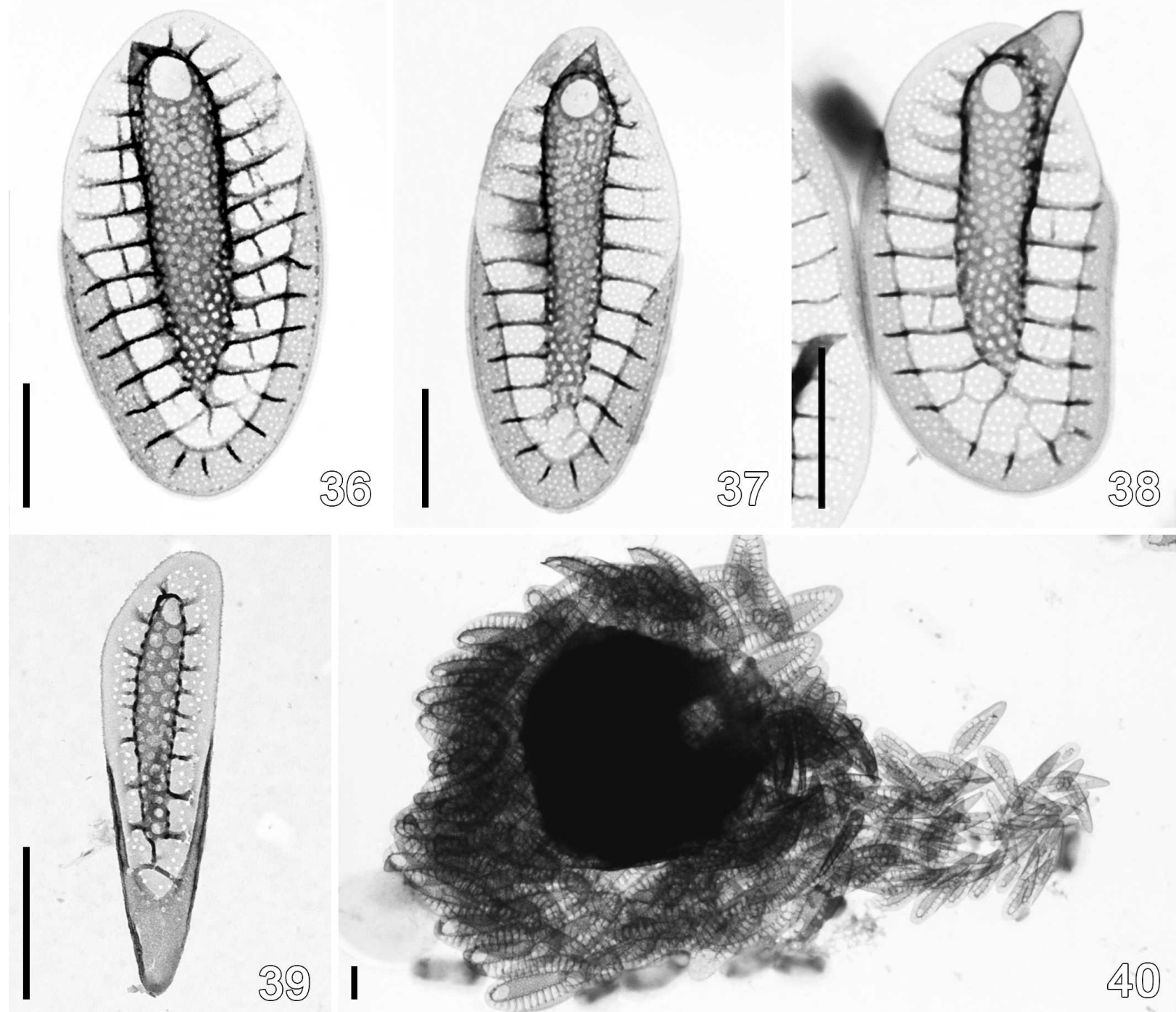

39) I a fun
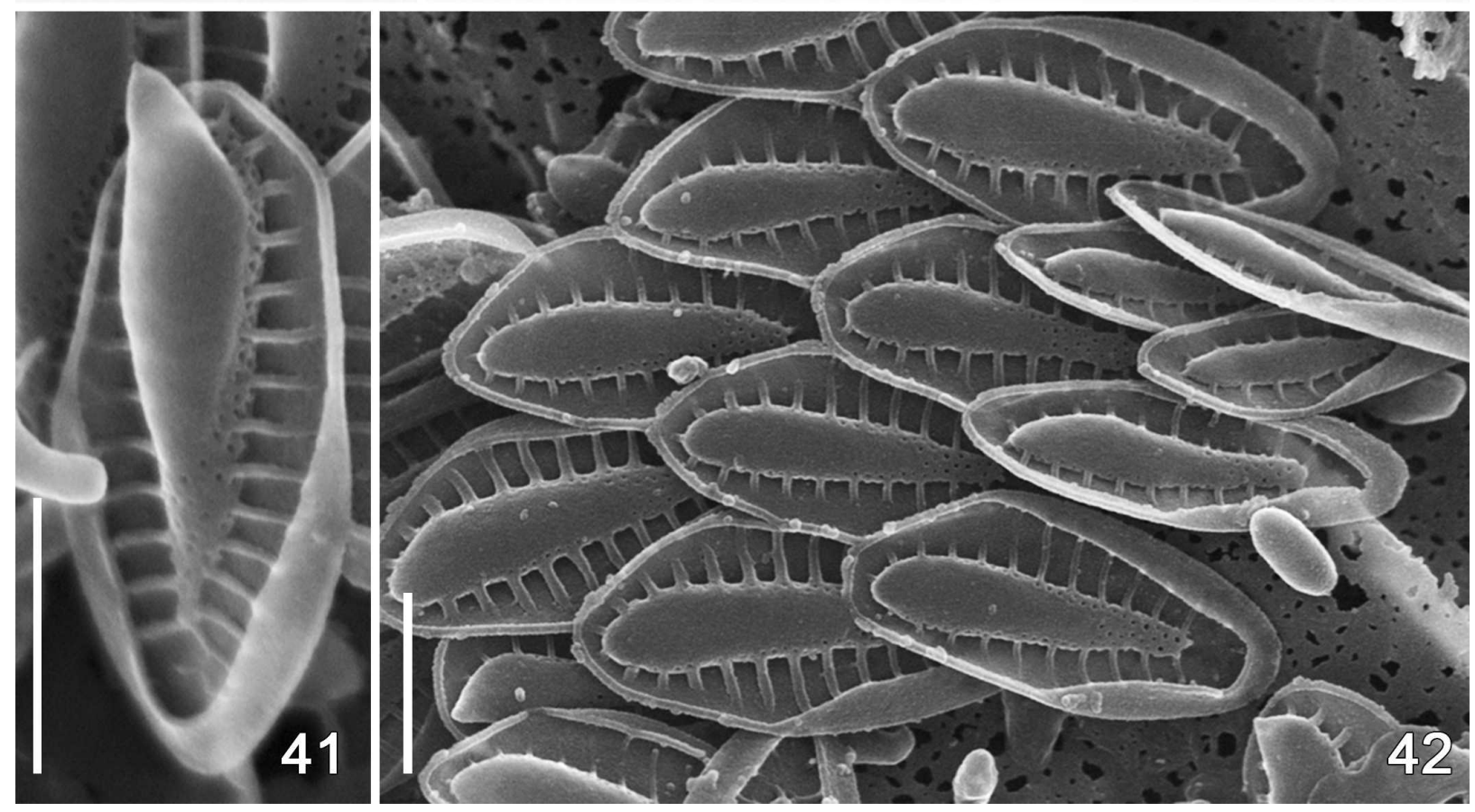
in absolute congruence with $S$. petersenii (see above). $S$. petersenii $\mathrm{f}$. bonaerensis was distinguished from the type by heavily silicified scales (Vigna 1979). However, the same type of scale has frequently been observed in our cultures of S. petersenii sensu stricto (Fig. 15). Also, Vigna (1979) described the form on the basis of her observations of the scales in the SEM only. By this technique, the scales of an organism appear more heavily silicified than when viewed in TEM (compare Fig. 52 with Fig. 58). All other characteristics of $S$. petersenii f. bonaerensis (e.g. scale dimensions, keel ending with a projecting spine) clearly correspond with $S$. petersenii sensu stricto (clade 3; Fig. 1). Interestingly, our proposed synonymization of $S$. petersenii f. kufferathii and $S$. petersenii f. bonaerensis with the type has already been considered by Nicholls \& Gerrath (1985).

Clade 6 (Fig. 1) morphologically corresponds with description of $S$. glabra. Similarly to $S$. petersenii, S. glabra was first described as a separate species based on observations of silica scales under the light microscope (Korshikov 1929). Electron micrographs subsequently provided more information on scale morphology (Petersen $\&$ Hansen 1956). The dimensions of body scales (length 2.7-3.0 $\mu \mathrm{m}$, width $2.0-2.2 \mu \mathrm{m}$ ) agree with our observations for clade 6 (length $2.5-3.3 \mu \mathrm{m}$, width $1.7-2.1 \mu \mathrm{m}$ ), as well as all other features reported by Petersen \& Hansen (1956): oval to rounded scale shape, less silicified scales (struts simple or absent), and a less developed, occasionally curved, central keel (Fig. 26). Similarly, the morphology of colonies we observed in S. glabra corresponds to the original description made by Korshikov (1929): 'The cells in colonies were grouped very densely, as compared with these of Synura petersenii, and were more rounded'. Interestingly, much circumstantial evidence points to $S$. glabra being a rather thermophilic species. Kies \& Berndt (1984) referred to the absence of $S$. glabra in water samples with temperature below $6.5^{\circ} \mathrm{C}$. Asmund (1968) referred to its complete absence in the cold waters of Alaska. Although $S$. glabra was later classified as a variety, or forma, of $S$. petersenii (Huber-Pestalozzi 1941; Kristiansen \& Preisig 2007), our present data clearly prove it to be a separate, morphologically and genetically well-defined species. In an effort to be consistent with the species names of $S$. petersenii and S. glabra we formally establish epitypes from the material we have investigated (see Taxonomic revision and diagnoses).

Clade 5 (Fig. 1) corresponds morphologically with the description of $S$. petersenii $\mathrm{f}$. truttae Siver. This form was described by Siver (1987), and differentiated from $S$. petersenii on the basis of features observed under the SEM. S. petersenii f. truttae was characterized as having small body scales, apical scales with cylindrical spines with several teeth, and heavily silicified struts connected by transverse folds (Fig. 23). All features agree with our observations for clade 5. Moreover, our SEM examination of strain S 15.3 detected the presence of a large number of small knobs randomly scattered on the surface of the keel. This feature was thus far noted only for scales of $S$. petersenii f. truttae (Siver 1987; Siver \& Wujek 1993). Therefore, we can unquestionably assign $S$. petersenii $\mathrm{f}$. truttae to clade 5. Although this taxon is still classified as a forma of S. petersenii (Kristiansen \& Preisig 2007), all our data designate it as a separate well-defined species, morphologically, genetically and ecologically (see below). Since its description, $S$. petersenii f. truttae has been found in several localities in USA (Siver \& Wujek 1993, 1999; Siver \& Lott 2004), all localities being acidic, humic waters. All our strains were isolated from acidic peat bogs (Kynčlová et al. 2010), with pH 4.2-5.2. Synura truttae is therefore a purely acidobiontic species, closely resembling S. sphagnicola (Korshikov) Korshikov (Kristiansen \& Preisig 2007).

The three remaining clades (1, 2 and 4; Fig. 1), could not be assigned to any Synura taxon with known morphology of silica scales (Kristiansen \& Preisig 2007). However, the taxonomy of Synura is complicated by the existence of several validly descibed species, whose scale morphology has never been observed under the electron microscope (Fott \& Ludvík 1957). To avoid introduction of superfluous names, we carefully considered all previously described species, including those with unknown ultrastructure of silica scales, to check for their possible identity with any of these three clades. A total of 71 taxa of the genus Synura have been described so far (Guiry \& Guiry 2011; Index Nominum Algarum 2011), 42 of which are currently considered to be valid (Table 3 ). When observed by LM, the species affiliation to the sections Synura and Petersenianae can be well recognized according to the presence or absence of scales with distal spines (Kristiansen \& Preisig 2007). Accordingly, the majority of species with unknown scale ultrastructure can be unambiguously affiliated to the section Synura (Table 3). Excluding these taxa, as well as omitting those taxa in section Petersenianae with known ultrastructure of silica scales, only six taxa remain for our consideration: $S$. adamsii Smith emend. Nygaard, $S$. adamsii f. malabrica Philipose, S. caroliniana Whitford, S. elipidosa Skvortsov, S. intermedia Bioret ex Kufferath and S. virescens (Bory) Playfair.

Synura adamsii and $S$. adamsii f. malabrica are well differentiated from all other Synura species by their very long cells, though they may be some doubts as to their

$\leftarrow$

Figs 36-42. Scale morphology of $S$. petersenii (Figs 36-40: TEM, Figs 41-42: SEM). Scale bars represent $1 \mu \mathrm{m}$.

Fig. 36. Body scale with transverse folds interconnecting the struts (S 6.4).

Fig. 37. Body scale without transverse folds (S 7.7).

Fig. 38. Apical scale with a long protruding keel tip (S 7.7).

Fig. 39. Rear scale (S 6.4).

Fig. 40. Position of scales on the cell (S 7.7).

Fig. 41. Apical scale (S 7.7).

Fig. 42. Body scales and narrow rear scales (on the right) (S 7.7). 

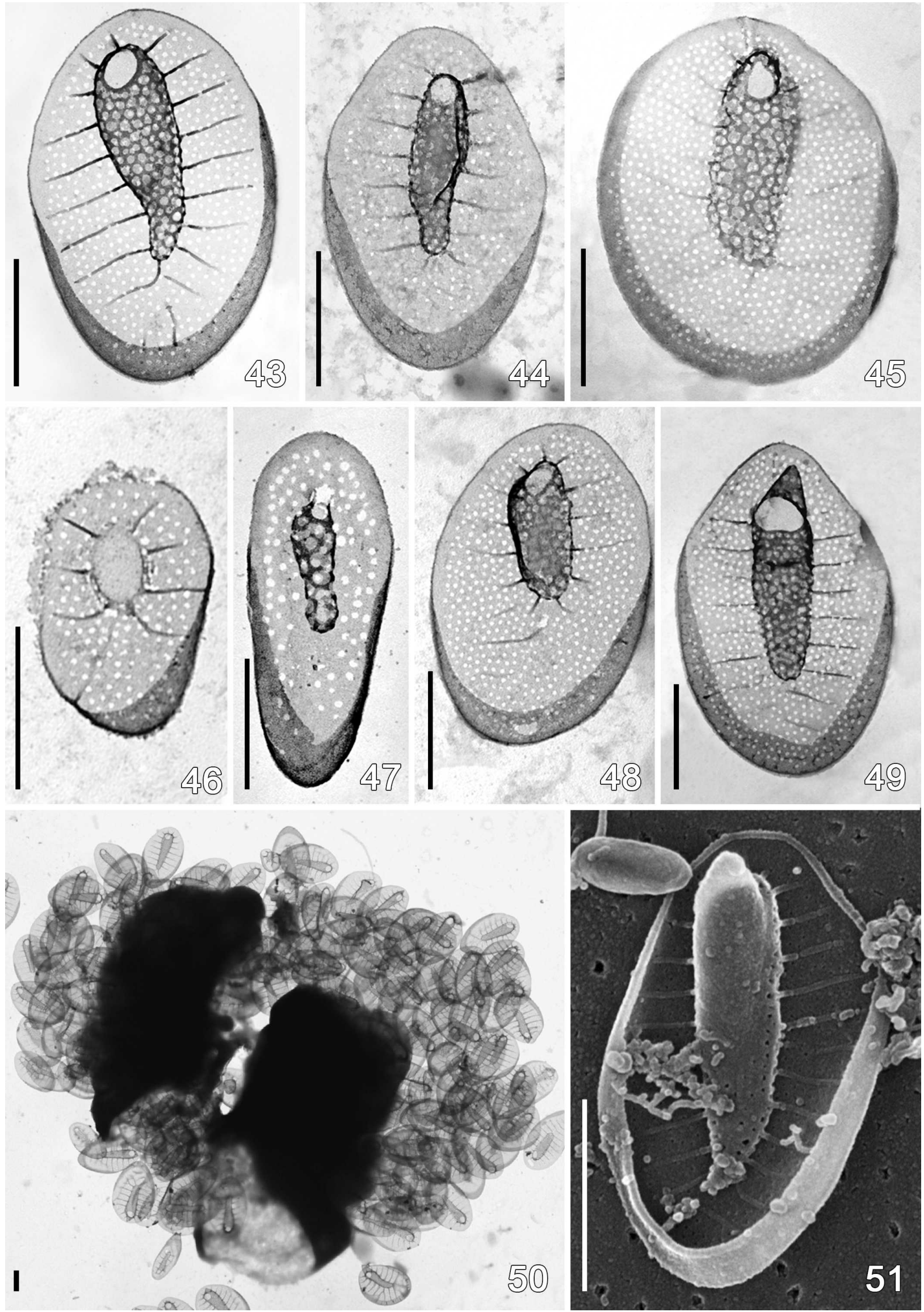
distinction from S. australiensis (Korshikov 1929). The second species with long cells, $S$. caroliniana, is distinguished by the stipitate form of its cells (Whitford 1943). In 1955, S. caroliniana was synonymized with $S$. petersenii, based on electron microscopy of silica scales (Manton 1955). The silica scales actually resemble those of $S$. petersenii sensu lato. These observations were made on a culture established by Dr L. Provasoli, and because of the cell dimensions and their obvious stipitate character, the cells of $S$. caroliniana do not correspond to any of our investigated lineages; therefore, we do not agree with the proposed synonymization. In our opinion, the electron microscopy performed by Manton (1955) was probably on a different species than that described by Whitford (1943). The other two species, S. elipidosa and S. virescens, are characterized by their smaller cell dimensions (Playfair 1921; Skvortsov 1961). This feature, together with the small number of cells forming one colony, differentiates them from all of our other investigated lineages. The last species, $S$. intermedia, can be distinguished from all other taxa in section Petersenianae by its very strong keel tip (Conrad 1946; Petersen \& Hansen 1958).

Consequently, because clades 1, 2 and 4 (Fig. 1) are not identical to any previously described species, and given that we are able to morphologically delimit these clades from all described taxa in section Petersenianae, we are proposing that they represent new species: $S$. conopea (Fig. 22), S. americana (Fig. 24) and S. macropora (Fig. 25). Consistent with our proposed taxonomic revision, section Petersenianae now includes 15 ultrastructurally well-defined taxa (i.e. 10 species and five formae). The most distinctive features for species recognition is the overall shape of body scales (rounded vs. lanceolate), scale dimensions, keel shape, number and distance of struts, amount of strut interconnections, and the size of base plate pores, keel pores, and base plate hole (Table 2, Figs 21-35). Our data demonstrate that at least some previously described formae of $S$. petersenii may represent distinct, individual species, and not ecotypes of a single, morphologically highly variable species, as speculated by Sandgren et al. (1996), for example. Moreover, the morphological characters proposed for species delimitation remain stable, regardless of experimental conditions (Martin-Wagenmann \& Gutowski 1995; Němcová et al. 2010; Řezáčová-Škaloudová et al. 2010; our observations).

In our judgment the pseudo-cryptic diversity within Petersenianae, especially within $S$. petersenii sensu lato, is much greater than that uncovered by recent research (Boo et al. 2010; Kynčlová et al. 2010). Pseudo-cryptic species can differ only slightly in the morphology of their silica scales. Several organisms described as different formae (Asmund 1968; Cronberg \& Kristiansen 1980; Siver 1987; Kristiansen et al. 1997), as well as some organisms with morphologically unique scales (e.g. Kristiansen 1992; Řezáčová \& Škaloud 2005), very probably represent separate species. However, it is premature to raise these formae to the rank of species until either molecular or detailed morphological data are available from cultured clones. Notwithstanding, it is now clear that all these formae [i.e. S. petersenii f. asmundiae (Fig. 32), f. bjoerkii (Fig. 33), f. columnata Siver (Fig. 35), f. praefracta Asmund (Fig. 34) and f. taymyrensis Kristiansen (Fig. 31)] do not belong in $S$. petersenii sensu stricto.

\section{Species concept of Synura, section Petersenianae}

The cryptic diversity within the $S$. petersenii complex underscores the necessity of modifying the morphological species concept of this group of organisms. Slight morphological differences, traditionally considered as ecotypes of one morphologically variable species, we have found to be species-specific differences. Our data point to the importance of detailed morphological evaluation of silica scales when estimating the diversity and distribution of Synura, section Petersenianae. Special attention must be paid to the shape and dimensions of the body scales. Morphological characteristics should preferably be traced for several scales to reduce misidentification. Even slight morphological differences may indicate the presence of new, not as yet described, pseudo-cryptic species. Ideally, the intraspecific morphological variability should be considered concurrently.

Further, morphological comparison of silica scales observed by both TEM and SEM showed TEM to be more reliable for correct species delimitation. For example, $S$. conopea can be confused with $S$. petersenii in the SEM, because the specific keel reticulation, which is characteristic of this species, is visible only by TEM. This is consistent with the SEM investigations of Boo et al. (2010), who failed to find any morphological features delimiting particular clades within $S$. petersenii complex. On the other hand, SEM observations can significantly complete TEM investigations by showing the overall design of the cell covering.

\section{Biogeographic implications}

Because all six investigated pseudo-cryptic species could be morphologically well discriminated, we were able to trace their distribution according to the previously published reports of $S$. petersenii sensu lato. The biogeography of

$\leftarrow$

Figs 43-51. Scale morphology of $S$. glabra (Figs 43-50: TEM, Fig. 51: SEM). Scale bars represent $1 \mu \mathrm{m}$.

Fig. 43. Body scale with developed struts (S 32.1).

Fig. 44. Body scale with less developed struts (S 32.2)

Fig. 45. Rounded body scale without struts (S 9.2).

Fig. 46. Apical scales (S 14.1).

Fig. 47. Rear scale (S 32.1).

Fig. 48. Body scale with short, less developed keel (S 14.1).

Fig. 49. Body scale with distinct acute keep tip (S 9.2).

Fig. 50. Position of scales on the cell (S 9.2).

Fig. 51. Body scale with developed struts (S 32.1). 

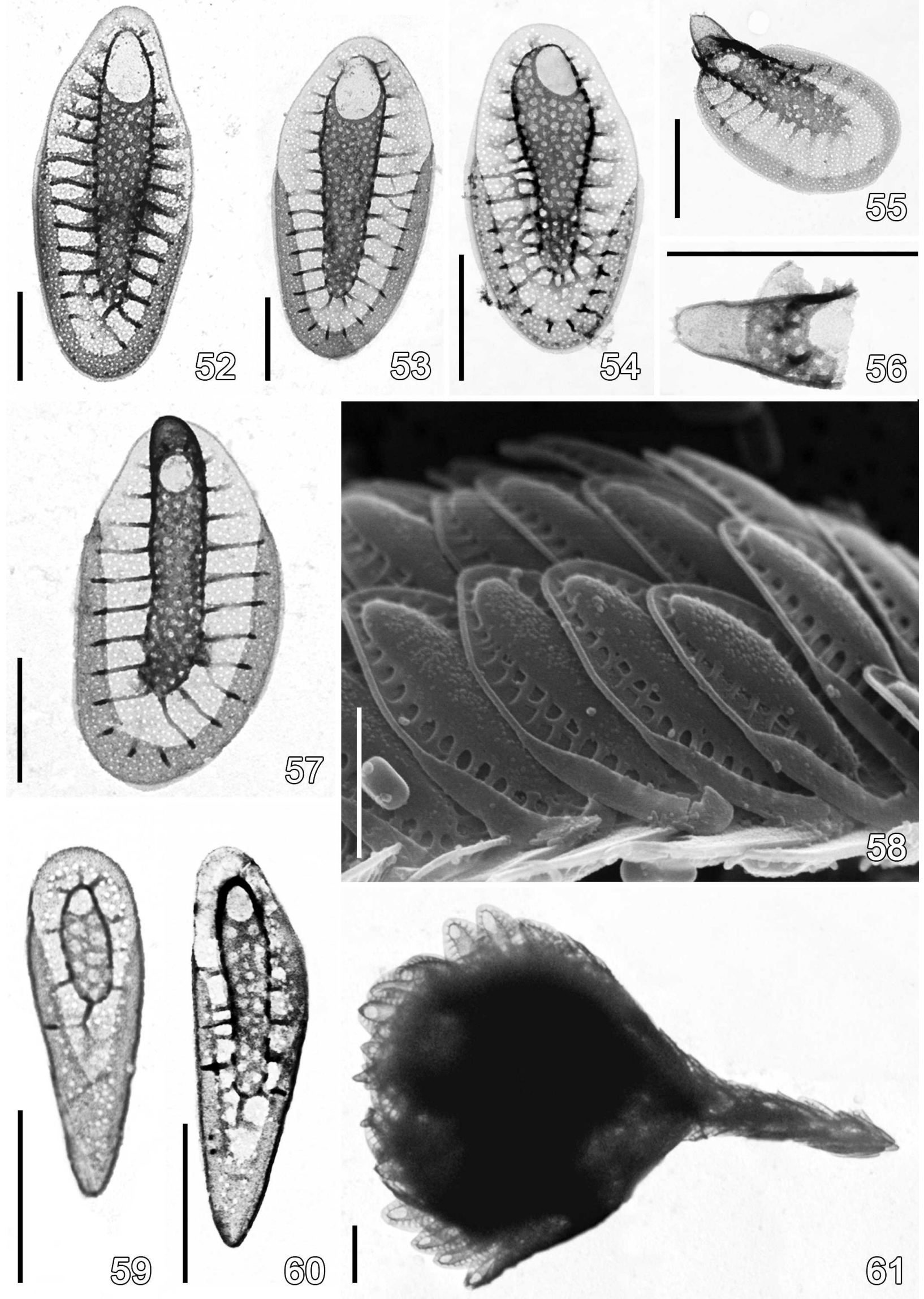
several lineages within the $S$. petersenii complex has been recently published by Boo et al. (2010), who described the existence of both cosmopolitan and regionally endemic cryptic species. However, the morphological data based on the published literature indicates that significant underestimation of species distribution occurs when based on molecular investigations only (Fig. 1).

A good example is the distribution of S. glabra. Boo et al. (2010) mentioned this species (Clade A) to occur in Korea, Japan and Czech Republic. Moreover, when they analyzed only their sequence database based on the 96 strains either isolated from different reservoirs in South Korea or obtained from seven international algal culture collections, the lineage appeared as strictly endemic to Korea and Japan (Boo et al. 2010, fig. S2). However, the morphological data document the wide distribution of $S$. glabra, which is recorded from 13 countries in Europe, Asia and America. Similarly, S. americana was reported by Boo et al. (2010) as a putative endemic species from North America (Clade C). Even if its dominant distribution in Canada and USA is well documented, silica scales of this species have been reported from Colombia, Denmark and Germany (Kies \& Berndt 1984; Kristiansen 1988; Cronberg 1989).

This implies that adding morphological data based on silica scale morphologies of particular lineages considerably increases our present knowledge about the biogeography of Synura species. Consequently, we conclude that morphological characterisation (if available) should be included in biogeographical studies of protists, since analyzing and interpreting only genetic data do not faithfully reflect their real distribution. By including morphological data many more findings may be included, representing more than 100 years of protist research. Moreover, analyzing such datasets will minimize the risk of sampling errors and extend the diversity of investigated habitats. Considering the small amount of genetic data available for almost every protist species, we feel that biogeographical studies based on only genetic data should be considered as preliminary.

\section{TAXONOMIC REVISIONS AND DIAGNOSES}

\section{Synura petersenii Korshikov 1929 emend. Škaloud \& Kynčlová}

Figs 36-42

SYNONYMS: Synura petersenii Korshikov f. kufferathii Petersen \& Hansen, Biologiske Meddelelser - Kongelige
Danske Videnskabernes Selskab (1958) 23: p. 10, fig. 5; $S$. petersenii Korshikov f. bonaerensis Vigna, Bolétin de la Sociedad Argentina de Botánica (1979) 18: p. 49, figs I, II; non S. caroliniana Whitford, Journal of the Elisha Mitchell Scientific Society (1943) 59: p. 159, figs 6, 7.

DESCRIPTION: Cells pyriform, $20-31 \mu \mathrm{m}$ long and $8-12 \mu \mathrm{m}$ wide, entirely covered with lanceolate scales. Body scales elongated, 3.6-4.6 $\mu \mathrm{m}$ in length and 1.8-2.3 $\mu \mathrm{m}$ in width (Figs 36, 37, 42). The cylindrical keel often terminates into an acute tip. It is ornamented by rather small pores (diameter $45-71 \mathrm{~nm}$ ). The ratio between scale and keel width varies from 2.7 to 3.8 . The basal plate, ornamented by numerous small pores (diameter 19-30 nm), is anteriorly perforated by a rounded base plate hole $0.24-0.36 \mu \mathrm{m}$ in diameter. Numerous struts (26-34), often interconnected by transverse folds, regularly extend from the keel to the edge of the scale. Spacing between the struts ranges from 0.24 to $0.28 \mu \mathrm{m}$. The presence and number of strut interconnections is highly variable (Figs 36-38). Scales lacking transverse folds and those with highly connected struts are observed in single cultures. However, scales without any transverse folds are only sporadically present, especially in several-monthsold cultures, due to silica depletion (Fig. 37). Apical scales more rounded, 3.2-3.7 $\mu \mathrm{m}$ in length and 1.6-2.4 $\mu \mathrm{m}$ in width (Figs 38, 41). The keels of apical scales terminate into rounded tips. Rear scales much smaller and narrow, 2.3$3.6 \mu \mathrm{m}$ in length and 0.7-1.2 $\mu \mathrm{m}$ in width (Figs 39, 42).

LECTOTYPE (HERE DESIGNATED): Korshikov (1929), fig. 54.

EPITYPE (HERE DESIGNATED): To clarify application of the name, an epitype is herein designated (cf. Pröschold \& Leliaert 2007): Synura petersenii strain S 7.7, frozen material deposited at the Culture Collection of Algae of Charles University in Prague (CAUP, Department of Botany, Charles University in Prague, Benátská 2, 12801 Prague 2, Czech Republic). Fig. 11 is an illustration of the epitype.

REFERENCE STRAIN: The live culture of the epitype (strain S 7.7) has been deposited as CAUP B 703 in the Culture Collection of Algae of the Charles University of Prague, Czech Republic (http://botany.natur.cuni.cz/algo/caup.html).

ETYMOLOGY: Korshikov (1929) named the species in honour of J.B. Petersen, who first observed the structure of the silica case around the cells using the name of $S$. uvella (Petersen 1918).

IDENTIFICATION: Synura petersenii could be unambiguously identified by its large scale dimensions, lanceolate

Figs 52-61. Scale morphology of $S$. truttae (Figs 52-57, 59-61: TEM, Fig. 58: SEM). Scale bars represent $1 \mu \mathrm{m}$.

Fig. 52. Typical lanceolate body scale (15.3).

Fig. 53. Body scale with indefinite indications of interconnections between struts (15.3).

Fig. 54. Body scale with number of transverse folds connecting the struts (15.9).

Fig. 55. Apical scale with three teeth on a rounded keel tip (15.3).

Fig. 56. Detail of an apical scale keel tip with four teeth (15.9).

Fig. 57. Apical scale with toothless rounded keel tip (15.9).

Fig. 58. Arrangement of the body scales on the cell. Note the keel covered by number of small bumps (15.3).

Fig. 59. Rear scale (15.3).

Fig. 60. Rear scale (15.9).

Fig. 61. Position of scales on the cell (15.9). 

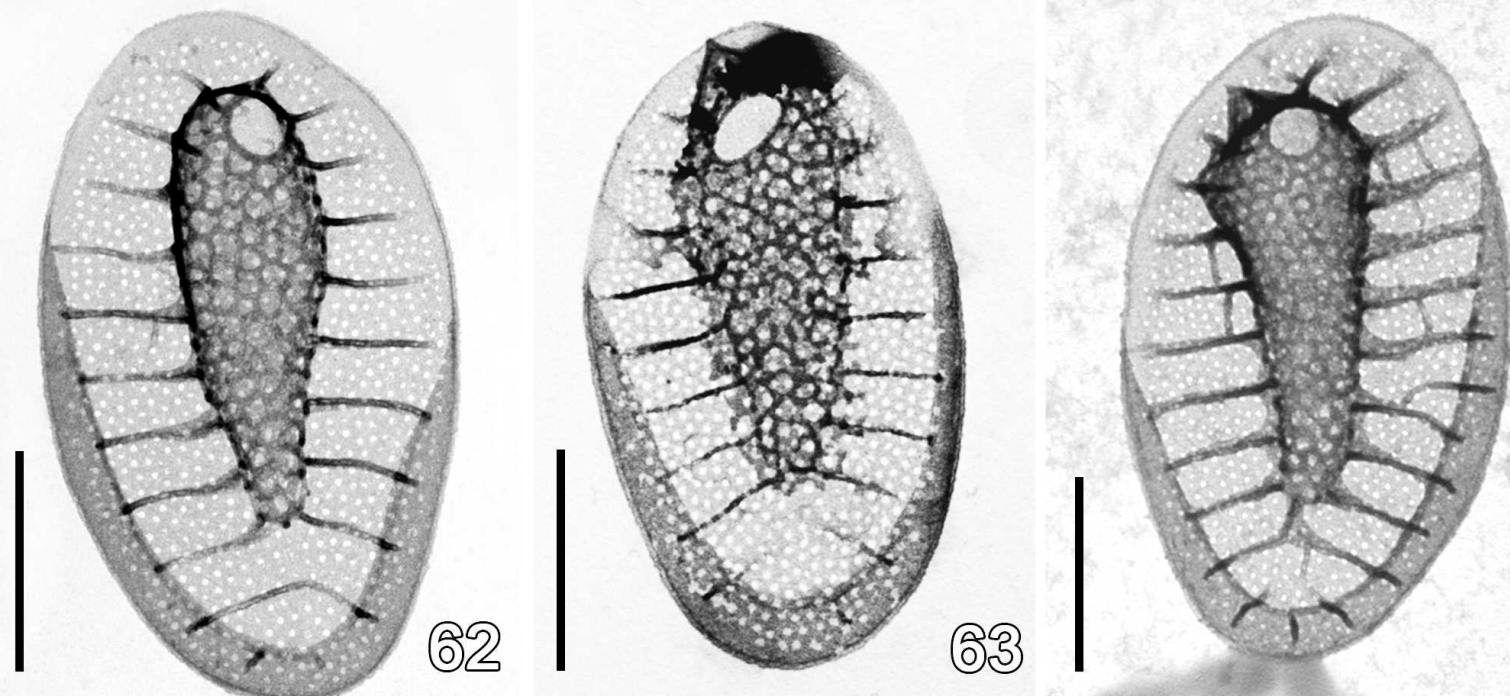

(3) 4
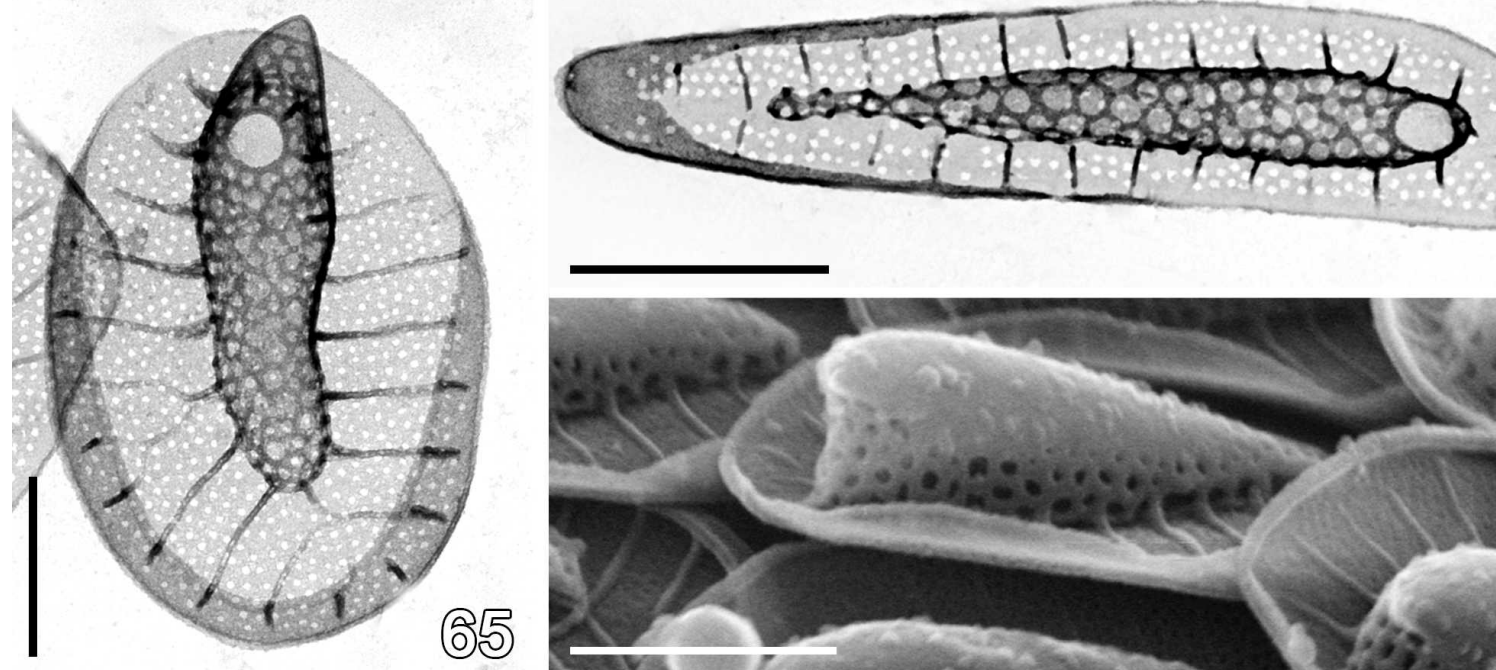

(อ)
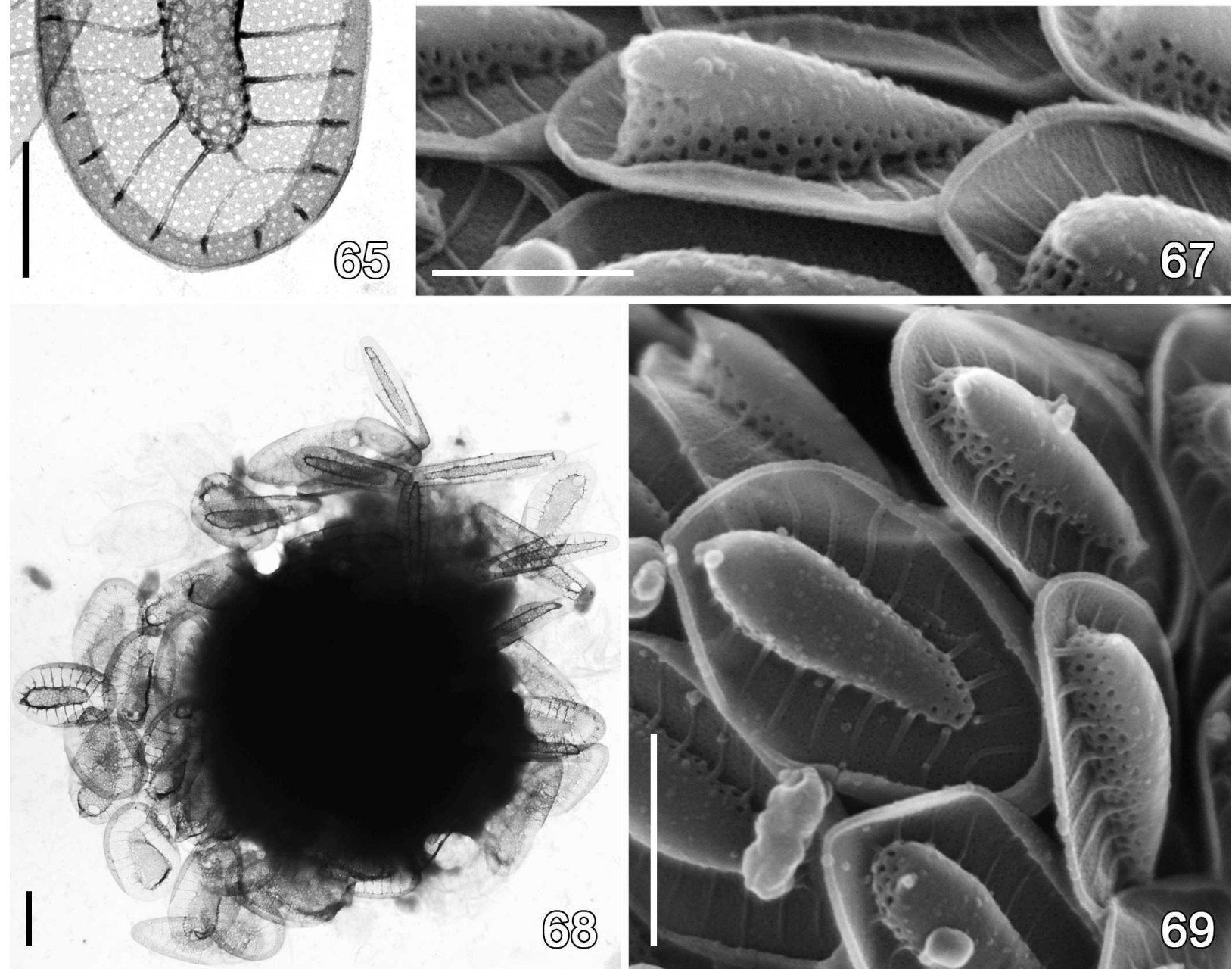
scale shape, common presence of transverse folds and a distinct keel tip in the majority of body scales.

DISTRIBUTION: Widely distributed. The molecular data confirm its presence in the Czech Republic, Germany, USA, Australia, Korea, UK and Portugal (Wee et al. 2001; Boo et al. 2010; Kynčlová et al. 2010). In addition, the above-mentioned morphological characteristics allow us to reassign several previously reported species of $S$. petersenii sensu lato to this species. According to the literature, $S$. petersenii sensu stricto very probably occurs in Argentina (Kristiansen \& Vigna 2002, figs 31-35), Brazil (Kristiansen \& Menezes 1998, figs 34-35), Canada (e.g. Nicholls \& Gerrath 1985, fig. 11), Chile (Dürrschmidt 1982, fig. 73), China (Kristiansen \& Tong 1989, fig. 62), Denmark (Petersen \& Hansen 1956, figs 1-3), Finland (e.g. Ikävalko 1994, fig. 41), Greece (Kristiansen 1980, fig. 41), Greenland (e.g. Jacobsen 1985, fig. 32), Hungary (e.g. Barreto 2005, fig. $8 \mathrm{f}-\mathrm{h}$ ), Iceland (Bradley 1964, fig. 43), Madagascar (Hansen 1996, fig. 2), Netherlands (Wujek \& van der Veer 1976, fig. 23), New Zealand (Wujek \& O'Kelly 1992, fig. 2B,C), Romania (Péterfi 1965, figs 4-8), Russia (Siver et al. 2005, figs 7A, 7B) and Sri Lanka (Dürrschmidt \& Cronberg 1989, fig. 38).

\section{Synura glabra Korshikov 1929 emend. Kynčlová \& Škaloud}

Figs 43-51

SYNONYMS: Synura petersenii Korshikov var. glabra $\mathrm{Hu}-$ ber-Pestalozzi nom. prov., Das Phytoplankton des Süsswassers. 2,1. Chrysophyceen, farblose Flagellaten, Heterokonten. In: Thienemann, A. (ed.): Die Binnengewässer XVI (1941) 2: p. 144; Synura petersenii Korshikov f. glabra Kristiansen \& Preisig, Chrysophyte and Haptophyte Algae, 2 Teil/Part 2: Synurophyceae. In: Büdel, Gärtner, Krienitz, Preisig \& Schagerl (eds): Süsswasserflora von Mitteleuropa Band 1/2: p. 118.

DESCRIPTION: Cells spherical to pyriform, 19-28 $\mu \mathrm{m}$ long and $10-14 \mu \mathrm{m}$ wide, very densely grouped in colonies, and the stalks are therefore barely discernable (Fig. 4). Body scales oval to almost spherical, less silicified, $2.4-3.4 \mu \mathrm{m}$ in length and 1.5-2.4 $\mu \mathrm{m}$ in width (Figs 43-45, 51). The keel less developed, usually without a keel tip or terminating into a small acute tip (Figs 48, 49). Keel ornamented by medium-sized pores (diameter 66-100 nm). The keel usually very narrow, the ratio between scale and keel width varies from 3.6 to 5.0. The basal plate, ornamented by numerous medium-sized pores (diameter $29-40 \mathrm{~nm}$ ), is anteriorly perforated by a rounded base plate hole $0.14-0.32 \mu \mathrm{m}$ in diameter. Struts somewhat reduced or absent, never interconnected by transverse folds. Their number varies from 17 to 22 . The spacing between the struts ranges from 0.25 to $0.29 \mu \mathrm{m}$. Apical scales smaller and more rounded, 1.6-2.6 $\mu \mathrm{m}$ in length and $1.2-1.9 \mu \mathrm{m}$ in width, morphologically similar to the body scales (Fig. 46). Rear scales much narrower, 1.9-2.9 $\mu \mathrm{m}$ in length and $1.0-1.3 \mu \mathrm{m}$ in width (Fig. 47).

LECTOTYPE (HERE DESIGNATED): Korshikov (1929), fig. 60.

EPITYPE (HERE DESIGNATED): Synura glabra strain S 32.2, frozen material deposited at the Culture Collection of Algae of Charles University in Prague (CAUP, Department of Botany, Charles University in Prague, Benátská 2, 12801 Prague 2, Czech Republic). Fig. 44 is an illustration of the epitype.

REFERENCE STRAIN: The live culture of the epitype (strain S 32.2) has been deposited as CAUP B704 in the Culture Collection of Algae of Charles University in Prague, Czech Republic (http://botany.natur.cuni.cz/algo/caup. html).

ETYMOLOGY: Korshikov (1929) chose the epithet 'glabra', which is an adjective in the feminine gender meaning 'bald' or 'bare'. He referred to the peculiar feature of this species as follows: 'Even under the highest magnification the cells appear quite smooth and deprived of any dense envelope'.

IDENTIFICATION: Synura glabra is unambiguously identified by its less silicified, oblong to oval scales with a small, narrow and sometimes bent keel. In the light microscope, the species is distinguished by its densely grouped spherical cells, which appear quite smooth even under the highest magnification $(1000 \times)$.

DISTRIBUTION: Widely distributed. Czech Republic, Canada (e.g. Nicholls \& Gerrath 1985), China (e.g. Kristiansen \& Tong 1989, fig. 63), Denmark (e.g. Petersen \& Hansen 1956, figs 4, 5), Finland (e.g. Ikävalko 1994, figs 39-40), Germany (Kies \& Berndt 1984), Hungary (Barreto 2005, fig. $8 \mathrm{~m}$ ), Japan (Takahashi 1967, figs 26, 28), Korea (Kristiansen et al. 1990, fig. 39; Boo et al. 2010), Netherlands (Wujek \& van der Veer 1976, fig. 21), Romania (Péterfi 1965), Russia (e.g. Kristiansen et al. 1997, fig. 27), and USA (Wujek \& Carter 2002, fig. 14).

$\leftarrow$

Figs 62-69. Scale morphology of $S$. americana (Figs 62-66, 68: TEM; Figs 67, 69: SEM). Scale bars represent 1 $\mu$ m.

Fig. 62. Typical body scale with well developed struts and no interconnections. The keel is wide near the base plate hole and markedly narrower on the opposite side of the scale (CCMP 862).

Fig. 63. Body scale with acute keel tip (CCMP 866).

Fig. 64. Body scale with interconnected struts (CCMP 862).

Fig. 65. Apical scale (CCMP 862).

Fig. 66. Rear scale (CCMP 862).

Fig. 67. Side view of body scale (CCMP 862).

Fig. 68. Position of scales on the cell (CCMP 866).

Fig. 69. Arrangement of body scales (CCMP 862). 

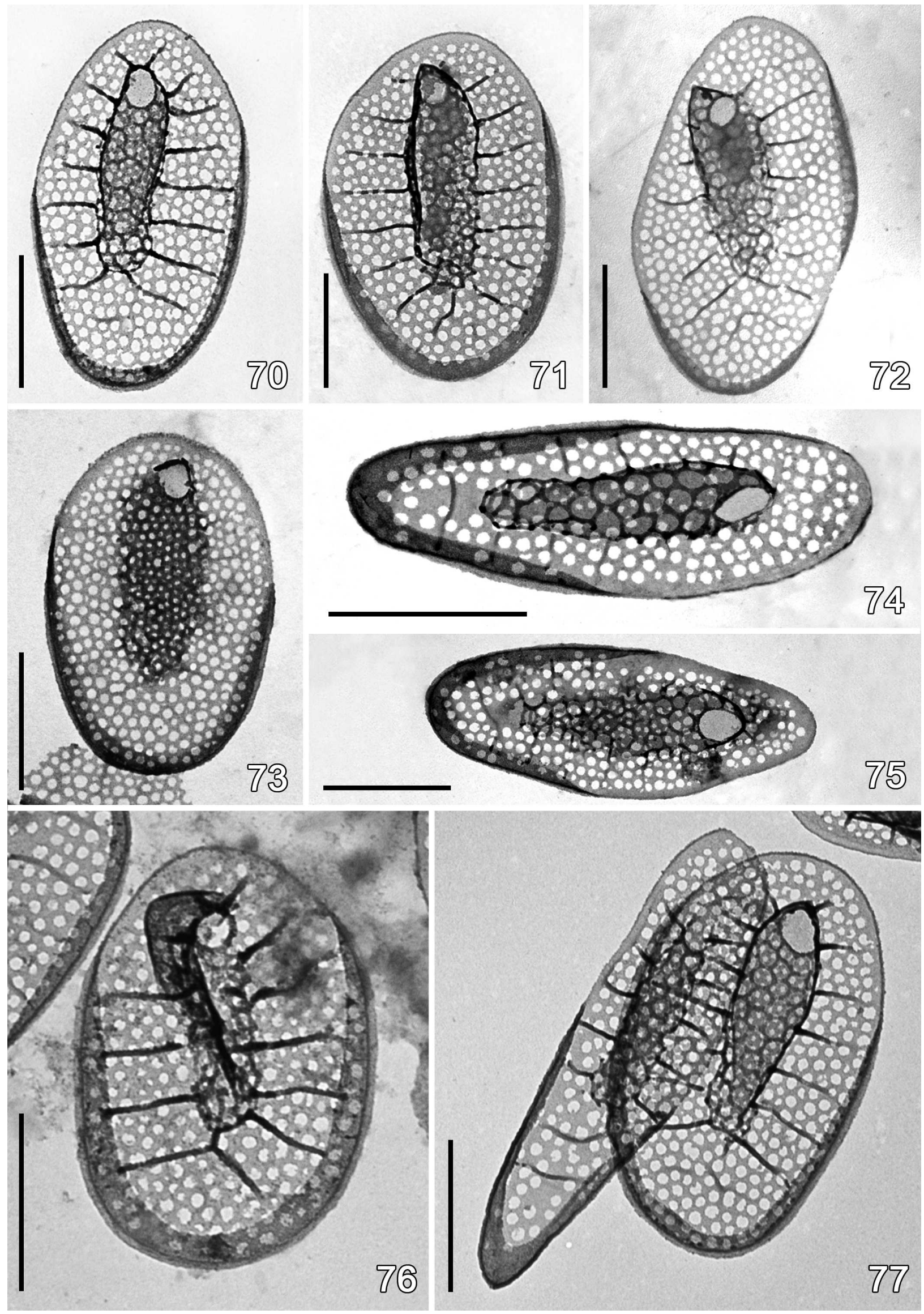


\section{Synura truttae (Siver) Škaloud \& Kynčlová comb. et stat. nov.}

Figs 52-61

BASIONYM: Synura petersenii Korshikov f. truttae Siver, Nordic Journal of Botany (1987) 7: p. 111, figs 12-14.

DESCRIPTION: Cells pyriform, 22-31 $\mu \mathrm{m}$ long and 11$13 \mu \mathrm{m}$ wide, entirely covered by lanceolate scales. Body scales elongated, 3.3-3.8 $\mu \mathrm{m}$ in length and $1.5-1.8 \mu \mathrm{m}$ in width (Figs 52-54). The keel of the body scales has no apparent tip or a much reduced one, ornamented by small pores (diameter $47-70 \mathrm{~nm}$ ). The ratio between scale and keel width varies from 2.3 to 2.8. In SEM images, the keel is covered by a number of small bumps (Fig. 58). The basal plate, ornamented by numerous small pores (diameter 18$22 \mathrm{~nm}$ ), is anteriorly perforated by a large, rounded to oblong base plate hole $0.32-0.56 \mu \mathrm{m}$ in diameter (Fig. 52). Numerous struts (27-33), which are often interconnected, regularly extend from the keel to the edge of the scale. Scales almost lacking transverse folds occur, especially in several-monthsold cultures, due to silica depletion (Fig. 53). The spacing between the struts ranges from 0.19 to $0.24 \mu \mathrm{m}$. Apical scales smaller and more rounded, 2.6-3.2 $\mu \mathrm{m}$ in length and 1.5$1.8 \mu \mathrm{m}$ in width (Figs 55, 57). The keel of the apical scales terminates into a rounded tip. Frequently, the keel tip has several (two to four) very short teeth on its top end (Figs 55, 56). Rear scales much smaller and narrow, 2.1-3.1 $\mu \mathrm{m}$ in length and 0.6-0.9 $\mu \mathrm{m}$ in width (Figs 59-60).

HOLOTYPE: Siver (1987), fig. 12 (iconotypus).

EPITYPE (HERE DESIGNATED): Synura truttae strain S 15.3., frozen material deposited at the Culture Collection of Algae of Charles University in Prague (CAUP, Department of Botany, Charles University in Prague, Benátská 2, 12801 Prague 2, Czech Republic). Fig. 52 is an illustration of the epitype.

REFERENCE STRAIN: The live culture of strain S 34.1 has been deposited as CAUP B705 in the Culture Collection of Algae of Charles University in Prague, Czech Republic (http://botany.natur.cuni.cz/algo/caup.html).

ETYMOLOGY: The epithet 'truttae' comes from Trout Lake (CT, USA), where the dominant population of this species was recorded (Siver 1987).

IDENTIFICATION: Synura truttae is unambiguously identified by its small scale dimensions, lanceolate scale shape, short distance between struts, common presence of transverse folds, absence of keel tips in body scales and large base plate hole.
DISTRIBUTION: Czech Republic, USA (e.g. Siver 1987; Siver \& Wujek 1993, 1999; Siver \& Lott 2004).

\section{Synura americana Kynčlová \& Škaloud sp. nov.}

Figs 62-69

Squamae corporis ovatae, 3.0-4.2 $\mu \mathrm{m}$ longae et 1.7-2.3 $\mu \mathrm{m}$ latae. Carina cum cuspide acuta. Multae costae praesentes. Pori laminae basalis medii (diameter 15-34 nm), pori carinae etiam medii (diameter $38-86 \mathrm{~nm}$ ). Apertura parva in lamina basali sub spina (diameter 83-274 $\mathrm{nm}$ ). Squamae anteriores

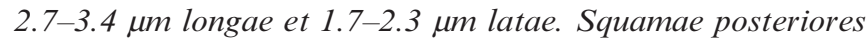
longae et angustae, 3.6-5.3 $\mathrm{m}$ longae et 0.9-1.3 $\mu \mathrm{m}$ latae.

DESCRIPTION: Cells pyriform, 22-28 $\mu \mathrm{m}$ long and $8-$ $12 \mu \mathrm{m}$ wide, entirely covered by rounded scales. Body scales 3.0-4.2 $\mu \mathrm{m}$ in length and $1.7-2.3 \mu \mathrm{m}$ in width (Figs 62-64, 67, 69). The keel often terminates into an acute tip. It is ornamented by medium-sized pores (diameter $38-86 \mathrm{~nm}$ ). Sometimes the keel is anteriorly widened (Figs 62, 63), giving it a triangular shape. The ratio between scale and keel width varies from 2.8 to 3.5 . The basal plate, ornamented by numerous small pores (diameter 15-34 $\mathrm{nm}$ ), is anteriorly perforated by a rounded base plate hole $0.08-0.27 \mu \mathrm{m}$ in diameter. Numerous struts (21-24) extend regularly from the keel to the edge of the scale but almost never interconnected by transverse folds (Figs 62, 63). However, when cultivated in silica-rich medium, transverse folds were occasionally observed (Fig. 64). The spacing between the struts ranged from 0.27 to $0.30 \mu \mathrm{m}$. Apical scales 2.7$3.4 \mu \mathrm{m}$ in length and $1.7-2.3 \mu \mathrm{m}$ in width (Fig. 65). The keel of the apical scales terminates into a rounded tip. Rear scales long and narrow, 3.6-5.3 $\mu \mathrm{m}$ in length and $0.9-1.3 \mu \mathrm{m}$ in width (Fig. 66). Their length often exceeds that of the body scales (Fig. 68).

HOLOTYPE (HERE DESIGNATED): Synura americana strain CCMP 862, frozen material deposited at the Culture Collection of Algae of Charles University in Prague (CAUP, Department of Botany, Charles University in Prague, Benátská 2, 12801 Prague 2, Czech Republic). Fig. 64 is an illustration of the epitype.

REFERENCE STRAIN: The live culture of the holotype, deposited as CCMP 862 at the Provasoli-Guillard National Center for Culture of Marine Phytoplankton in Maine, USA (https://ccmp.bigelow.org/).

TYPE LOCALITY: Winter's Creek, Keeweenaw County, MI, USA $\left(47^{\circ} 17^{\prime} 30.12^{\prime \prime} \mathrm{N} 88^{\circ} 4^{\prime} 19.56^{\prime \prime} \mathrm{W}, 189 \mathrm{~m}\right.$ asl).

$\leftarrow$

Figs 70-77. Scale morphology of S. macropora (TEM). Scale bars represent $1 \mu \mathrm{m}$.

Fig. 70. Typical body scale without distinct keel tip (S 14.2).

Fig. 71. Body scale with well developed simple struts and distinct short keel tip (S 5.3).

Fig. 72. Body scale with less developed struts (S 14.2).

Fig. 73. Body scale without struts (S 5.3).

Fig. 74. Rear scale (S 14.2).

Fig. 75. Rear scale (S 5.3).

Fig. 76. Apical scale with rounded keel tip (S 14.2).

Fig. 77. Rear (on the left) and body (on the right) scale. Note that the length of the rear scale exceeds that of the body scale (S 14.2). 

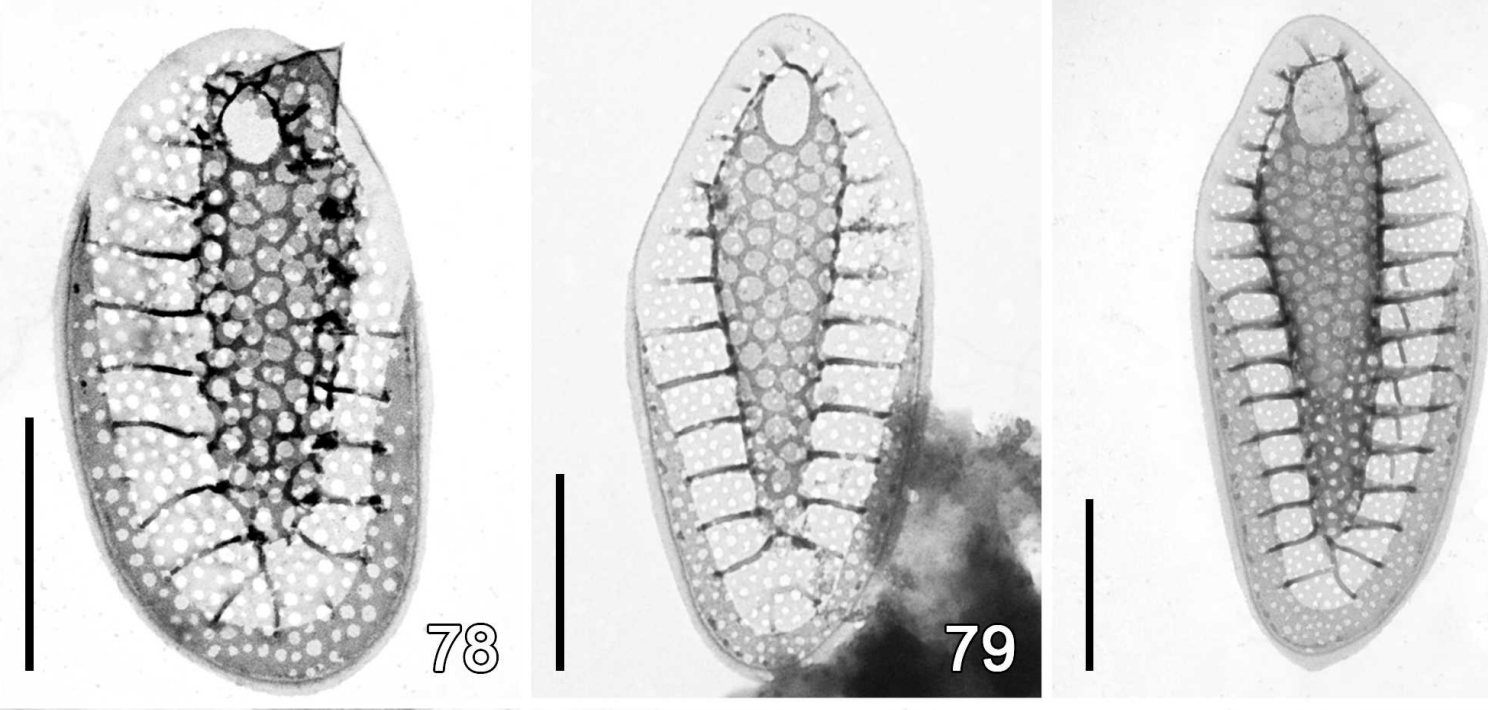

80)
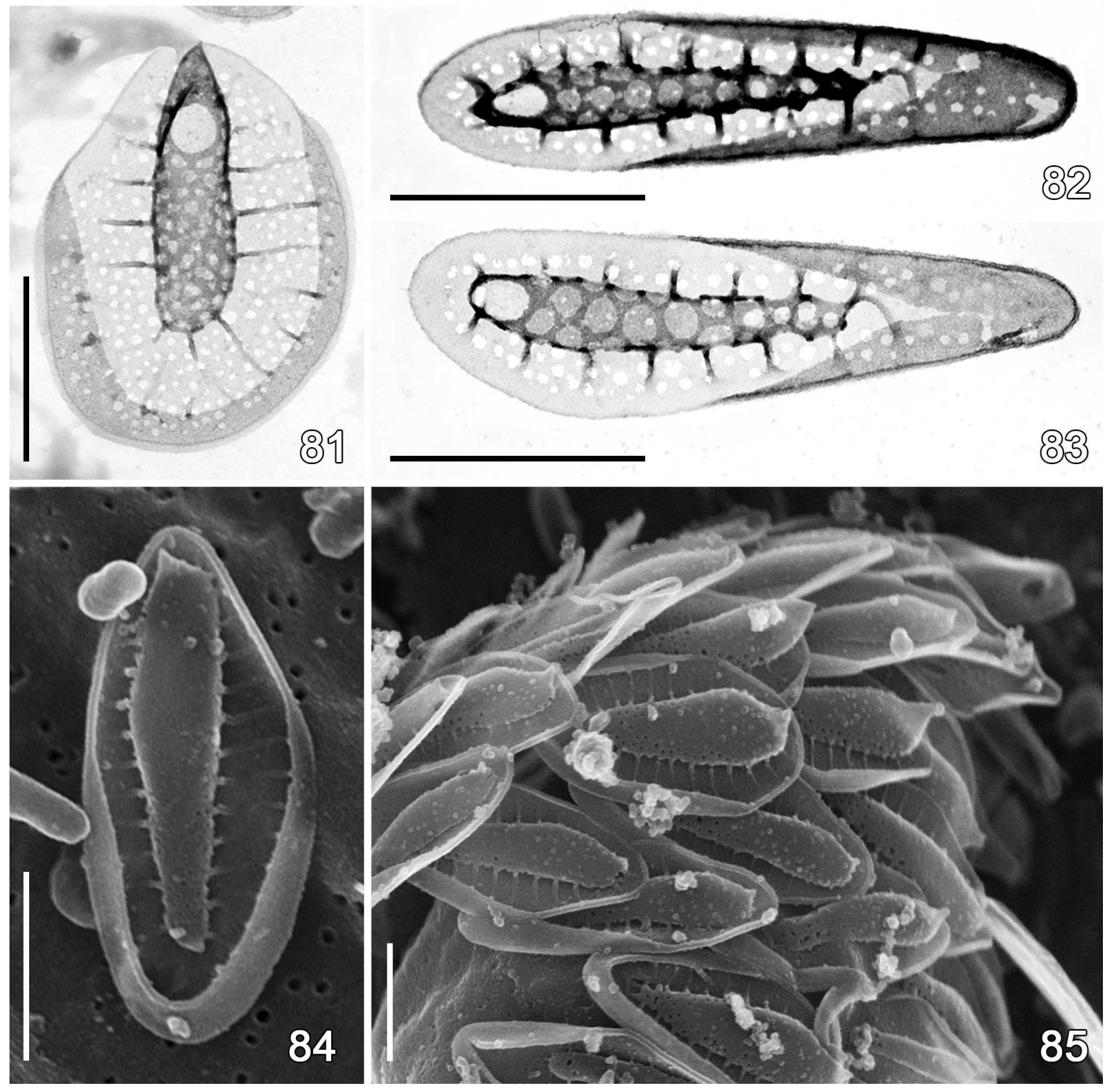
ETYMOLOGY: The specific epithet 'americana' is Latin for the common occurrence of the species in the North American continent.

IDENTIFICATION: Synura americana is unambiguously identified by its rounded scales, near absence of transverse folds, occasional triangular shape of the keel, and long rear scales.

DISTRIBUTION: The molecular data confirm its presence in USA and Canada (Wee et al. 2001). In addition, the abovementioned morphological characteristics have allowed us to trace its distribution from previously published reports of $S$. petersenii sensu lato. This species is common in North America (e.g. Kling \& Kristiansen 1983, fig. 73; Kristiansen 1975, figs 20-21; Nicholls \& Gerrath 1985, figs 8-9; Wee 1981, figs 1-2). Moreover, it has been found in Colombia (Cronberg 1989), Denmark (Kristiansen 1988; fig. 8C) and Germany (Kies \& Berndt 1984; fig. I 2).

\section{Synura macropora Škaloud \& Kynčlová sp. nov.}

Figs $70-77$

Squamae corporis ovatae, 2.6-3.5 $\mu$ m longae et 1.5-2.2 $\mu \mathrm{m}$ latae. Carina cum cuspide parva acuta. Costae parvae aut absentes. Pori laminae basalis magni (diameter 53-77 nm), pori carinae etiam magni (diameter 85-137 nm). Apertura parva in lamina basali sub spina (diameter 156-330 nm). Squamae anteriores 2.1-2.9 $\mu \mathrm{m}$ longae et 1.7-2.0 $\mu \mathrm{m}$ latae. Squamae posteriores parviores et rotundae, 3.5-4.7 $\mu \mathrm{m}$ longae et 0.9-1.4 um latae.

DESCRIPTION: Cells pyriform, 17-25 $\mu \mathrm{m}$ long and 8-12 $\mu \mathrm{m}$ wide, entirely covered with rounded scales. Body scales 2.6$3.5 \mu \mathrm{m}$ in length and 1.5-2.2 $\mu \mathrm{m}$ in width (Figs 70-73). The keel protrudes into an indistinct tip (Figs 71, 72) that may be absent (Fig. 70). The keel is ornamented by large pores (diameter $85-137 \mathrm{~nm}$ ). The ratio between scale and keel width varies from 2.7 to 3.6. Basal plate ornamented by distinct, large pores (diameter $53-77 \mathrm{~nm}$ ). It is anteriorly perforated by a rounded base plate hole $0.16-0.33 \mu \mathrm{m}$ in diameter. Struts may be short (Fig. 72) or absent (Fig. 73), never interconnected by transverse folds. Their number varies from 17 to 21 . Spacing between struts is the largest observed in any species, ranging from 0.29 to $0.33 \mu \mathrm{m}$. Apical scales 2.1-2.9 $\mu \mathrm{m}$ in length and 1.7-2.0 $\mu \mathrm{m}$ in width. The keel of the apical scales terminates into a distinct, rounded tip (Fig. 76). Rear scales long and narrow, 2.7$4.3 \mu \mathrm{m}$ in length and $0.9-1.4 \mu \mathrm{m}$ in width (Figs 74-75). Their length often exceeds that of the body scales (Fig. 77).
HOLOTYPE (HERE DESIGNATED): Synura macropora strain S 5.3, frozen material deposited at the Culture Collection of Algae of Charles University in Prague (CAUP, Department of Botany, Charles University in Prague, Benátská 2, 12801 Prague 2, Czech Republic). Fig. 71 is an illustration of the epitype.

TYPE LOCALity: Alluvial pool, Modřany, Prague, Czech

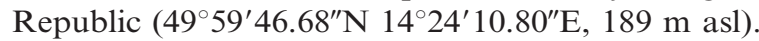

ETYMOLOGY: The specific epithet 'macropora' is a Latin expression for 'having large pores'. The epithet was chosen for the remarkably large keel pores and base plate pores typical of this species.

IDENTIFICATION: Synura macropora is unambiguously identified by its rounded scales with large keel and large base plate pores.

DISTRIBUTION: The molecular data confirm the presence of $S$. macropora in the Czech Republic only (Kynčlová et al. 2010). However, the above-mentioned morphological characteristics have allowed us to trace its distribution from the previously published reports of $S$. petersenii sensu lato. $S$. macropora has been found in Brazil (Couté \& Franceschini 1998), Germany (Kies \& Berndt 1984; figs I 4, 6; MartinWagenmann \& Gutowski 1995; figs 10-15) and Denmark (Kristiansen \& Preisig 2007; figs 38 A,B).

\section{Synura conopea Kynčlová \& Škaloud sp. nov.}

Figs 78-85

Squamae corporis lanceolatae, 3.3-4.1 $\mu \mathrm{m}$ longae et 1.4$1.9 \mu \mathrm{m}$ latae. Carina cum cuspide acuta. Multae costae praesentes. Pori laminae basalis medii (diameter $25-51 \mathrm{~nm}$ ), pori carinae medii vel magni (diameter 66-100 nm). Apertura parva in lamina basali sub spina (diameter 190$319 \mathrm{~nm}$ ). Squamae anteriores 2.8-3.4 $\mu \mathrm{m}$ longae et 1.4$1.8 \mu \mathrm{m}$ latae. Squamae posteriores multo parviores, angustae et simpliores, 2.2-3.5 $\mu \mathrm{m}$ longae et 0.6-1.0 $\mu \mathrm{m}$ latae.

DESCRIPTION: Cells pyriform, 20-28 $\mu \mathrm{m}$ long and $8-12 \mu \mathrm{m}$ wide, entirely covered with lanceolate scales. Body scales $3.3-4.1 \mu \mathrm{m}$ in length and $1.4-1.9 \mu \mathrm{m}$ in width (Figs 78-80, $84,85)$. The keel terminates into an acute tip, which may be absent (Figs 79, 80). If present, the tip is sometimes clearly directed toward the side of the scale (Fig. 78). The keel is usually broadened apically (Figs 79, 80), and ornamented by medium-sized to large pores (diameter $66-100 \mathrm{~nm}$ ). The ratio between scale and keel width varies from 2.4 to 2.7 . The basal plate, ornamented by numerous medium-sized

$\longleftarrow$

Figs 78-85. Scale morphology of $S$. conopea (Figs 78-83: TEM; Figs 84, 85: SEM). Scale bars represent $1 \mu$ m.

Fig. 78. Typical body scale with acute keel tip (S 10.2).

Fig. 79. Body scale with simple struts and lacking a distinct keel tip. The keel is wide near the base plate hole and markedly narrower on the opposite side of the scale (S 7.10).

Fig. 80. Body scale with interconnected struts (S 17.2).

Fig. 81. Apical scale (S 17.2).

Fig. 82. Rear scale (S 10.2).

Fig. 83. Rear scale (S 7.10).

Fig. 84. Body scale (S 17.2).

Fig. 85. Arrangement of body scales on the cell (S 17.2). 
pores (diameter $25-51 \mathrm{~nm}$ ), is anteriorly perforated by a rounded to oblong base plate hole $0.19-0.32 \mu \mathrm{m}$ in diameter. Numerous struts (24-30), which extend regularly from the keel to the edge of the scale, are usually not interconnected by transverse folds (Figs 78, 79). However, when cultivated in silica-rich medium, transverse folds were occasionally observed (Fig. 80). The spacing between struts ranges from 0.23 to $0.26 \mu \mathrm{m}$. Apical scales more rounded, 2.4-3.4 $\mu \mathrm{m}$ long and 1.4-1.8 $\mu \mathrm{m}$ wide (Fig. 81). The keel of the apical scales terminates into an acute or rounded tip. Rear scales much smaller and narrower, 2.2-3.5 $\mu \mathrm{m}$ in length and $0.6-1.0 \mu \mathrm{m}$ in width (Figs 82, 83).

HOLOTYPE (HERE DESIGNATED): Synura conopea strain S 7.10, frozen material deposited at the Culture Collection of Algae of Charles University in Prague (CAUP, Department of Botany, Charles University in Prague, Benátská 2, 12801 Prague 2, Czech Republic). Fig. 79 is an illustration of the epitype.

REFERENCE STRAIN: The living culture of the holotype (strain S 7.10) has been deposited as CAUP B707 in the Culture Collection of Algae of Charles University in Prague, Czech Republic (http://botany.natur.cuni.cz/algo/ caup.html).

TYPE LOCALITY: Babín pool, Žd̆árské vrchy PLA, Czech Republic $\left(49^{\circ} 32^{\prime} 31.92^{\prime \prime} \mathrm{N} 15^{\circ} 53^{\prime} 48.84^{\prime \prime} \mathrm{E}, 568 \mathrm{~m}\right.$ asl).

ETYMOLOGY: The specific epithet 'conopea' is a Latin expression for 'reticulose'. It was chosen due to the large and closely arranged keel pores, giving the keel a reticulate appearance.

IDENTIFICATION: Synura conopea is unambiguously identified by its lanceolate scale shape, near absence of transverse folds, and large and closely arranged keel pores. However, it may be confused with $S$. petersenii, especially in the SEM where the keel reticulation is not visible. Synura conopea can be distinguished from this species mainly by its somewhat smaller scale dimensions and its keel characteristics. Whereas the keel in $S$. petersenii is nearly cylindrical, in $S$. conopea it is usually much more broadened apically (compare Fig. 80 and Fig. 36). Therefore, the two species differ in the ratio between scale and keel width (Table 2).

DISTRIBUTION: The molecular data confirm the presence of S. conopea in the Czech Republic, (Kynčlová et al. 2010), USA, Japan and Korea (Boo et al. 2010). Moreover, the above-mentioned morphological characteristics have allowed us to trace its distribution from the previously published reports of $S$. petersenii sensu lato. According to the literature, $S$. conopea has been found in Argentina (Vigna \& Munari 2001, fig. 7), Brazil (Couté \& Franceschini 1998, figs 75-79), Greenland (Jacobsen 1985, fig. 33) and Ireland (̌̌ezáčová \& Škaloud 2005, fig. 34).

\section{Key to species of the genus Synura, section Petersenianae:}

1. Scales narrow and long (length more than $6.5 \mu \mathrm{m})$. . 2 Scales more rounded, length up to $5 \mu \mathrm{m} \ldots \ldots .3$

2. Keel short, the base plate with fine regular reticulation ............... longisquama
Keel long, the base plate with transverse struts . . . . . . . . . . . . . australiensis

3. Base plate with densely interconnected transverse struts ................... 4 Base plate with transverse struts, either simple without interconnections, or interconnected by single transverse struts. . . . . . . . . . . . . 5

4. Keel narrow, with a large base plate hole. . . . . . . . . . . . . . . . . . . . macracantha Keel extremely broad, with a very small base plate hole. . . . . . . . . . . . . . obesa

5. Scales with a very broad $\operatorname{rim} \ldots \ldots \ldots 6$ Rim of scales narrower . . . . . . . . . 7

6. Scales almost circular, with connected transverse struts. . . . . . . . "S. petersenii" f. asmundiae Scales oblong, transverse struts without interconnections . . . . . . . . . . "S. petersenii" f. bjoerkii

7. Keel and ribs less developed, scales often almost rounded. . . . . . . . . . . . . glabra Keel and ribs more developed, scales oval to lanceolate ................. 8

8. Inner portion of the rim ornamented by row of posts (in SEM) or dots (in TEM). . . . . . . . . . . . . ............ "S. petersenii" f. columnata Rim not ornamented . . . . . . . . . . . . . . 9

9. Keel of apical scales terminates into a rounded tip, provided with a number of small teeth. . . . . . 10 Keel of apical scales terminates into an acute tip. . 11

10. Body scales narrower, with 27-33 thickened and conspicuous struts ............. truttae Body scales broader, with 24-27 inconspicuous struts . . . . . . . . "S. petersenii" f. praefracta

11. Body scales oval and rounded, length to width ratio about 1.5; rear scales long . . . . . . . . . . 12 Body scales oblong-lanceolate, length to width ratio about 2; rear scales short. . . . . . . . . . . . 13

12. Base plate pores small . . . . . . . . . . americana Base plate pores very large. . . . . . . macropora

13. Keel pores small. . . . . . . . . . . . petersenii Keel ornamented by large pores . . . . . . . . . . 14

14. Length of body scales larger than $3.3 \mu \mathrm{m}$, keel pores

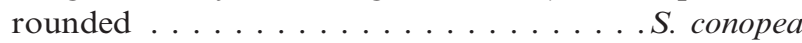
Length of body scales up to $2.8 \mu \mathrm{m}$, keel pores angular . . . . . . . . "S. petersenii" f. taymyrensis

\section{ACKNOWLEDGEMENTS}

The authors would like to thank Jørgen Kristiansen, James L. Wee and Peter A. Siver for valuable suggestions for improving the manuscript; to Paul Silva for providing literature that was difficult to obtain, and to Martina Pichrtová for supplying the Synura culture. We are grateful to Øjvind Moestrup for assistance in the final editing and reviewing process of this publication. The English style was kindly improved by Just Me-Editing. This work was supported by project No. P506/11/P056 of the Czech Science Foundation and the Institutional Research Concept AVOZ50200510. 


\section{REFERENCES}

Andersen R.A., Morton S.L. \& Sexton J.P. 1997. ProvasoliGuillard National Center for Culture of Marine Phytoplankton 1997 - list of strains. Journal of Phycology 33 (Suppl.): $1-75$.

Asmund B. 1968. Studies on Chrysophyceae from some ponds and lakes in Alaska. VI. Occurrence of Synura species. Hydrobiologia 31: 497-515.

AverintSEv S. 1901. Materialy k poznavaniju fauny prostejsich v okresnostjach Bologovskoj Biologicheskoj stancii. Trudy Presnovodnoi Biologicheskoi Stantsii Imperatorskago S.-Peterburgskago Obshchestva Estestvoispytatelei 1: 205-238.

BAlonov I.M. \& KuZmin G.V. 1974. Vidy roda Synura Ehrenberg (Chrysophyta) v vodokhranilischchakh Volzhskogo Kaskada. Botanicheskii Zhurnal 59: 1675-1686.

BAlONOv I.M. 1976. Rod Synura Ehr. (Chrysophyta). Biologija, Ekologija, Sistematika. Akademia Nauk SSSR, Institut Vnutrennich Vod, Trudy 31: 61-82.

BARRETO S. 2005. The silica-scaled chrysophyte flora of Hungary. Nova Hedwigia, Beiheft 128: 11-41.

Boo S.M., KIM H.S., SHIN W., Boo G.H., Cho S.M., Jo B.Y., KIM J.-H., Kim J.H., YANG E.C., Siver P.A., Wolfe A.P., Bhattacharya D., Andersen R.A. \& Yoon H.S. 2010. Complex phylogeographic patterns in the freshwater alga Synura provide new insights into ubiquity vs. endemism in microbial eukaryotes. Molecular Ecology 19: 4328-4338.

BORY DE SAInT Vincent J.B.G.M. 1824. Encyclopédie méthodique. Histoire naturelle des zoophytes, ou animaux rayonnés. Veuve Agasse, Paris. 819 pp.

BRADlEy D.E. 1964. A study of the Mallomonas, Synura and Chrysosphaerella of Northern Iceland. Journal of General Microbiology 37: 321-333.

Chodat R., Raineri R. \& Drew K. 1926. Algues de la région du Grand Saint-Bernard. Bulletin de la Société Botanique de Genève, série II 17: 202-217.

CONRAD W. 1946. Notes protistologiques. XXXI. Matériaux pour la morphologie des Synura Ehrenberg. Bulletin du Musee Royal d'Histoire Naturelle de Belgique 22: 1-12.

Couté A. \& FrANCESCHINI I.M. 1998. Scale-bearing chrysophytes from acid waters of Florianópolis, Santa Catarina Island, South Brazil. Archiv für Hydrobiologie, Supplement 123 / Algological Studies 88: 37-66.

Cronberg G. 1989. Scaled chrysophytes from the tropics. Nova Hedwigia, Beiheft 95: 191-232.

Cronberg G. \& Kristiansen J. 1980. Synuraceae and other Chrysophyceae from central Småland, Sweden. Botaniska Notiser 133: 595-618.

Croome R.L. \& Tyler P.A. 1985. Synura australiensis (Mallomonadaceae, Chrysophyceae), a light and electron microscopical investigation. Nordic Journal of Botany 5: 399-401.

DÜRRSCHMIDT M. 1982. Studies on the Chrysophyceae from South Chilean inland waters by means of scanning and transmission electron microscopy, II. Archiv für Hydrobiologie, Supplement 63 / Algological Studies 31: 121-163.

Dürrschmidt M. \& Cronberg G. 1989. Contributions to the knowledge of tropical chrysophytes: Mallomonadaceae and Paraphysomonadaceae from Sri Lanka. Archiv für Hydrobiologie, Supplement 82 / Algological Studies 45: 15-37.

EhrenberG C.G. 1834. Dritter Beitrag zur Erkenntnis großer Organisation in der Richtung des kleinsten Raumes. Abhandlungen der Königlichen Akademie der Wissenschaften zu Berlin 1833: 145-336.

FOTT B. \& Ludvík J. 1957. Die submikroskopische Struktur der Kieselschuppen bei Synura und ihre Bedeutung fur die Taxonomie der Gattung. Preslia 29: 5-16.

GUIRY M.D. \& GUIRY M.D. 2011. AlgaeBase. World-wide electronic publication, National University of Ireland, Galway. Available at: http://www.algaebase.org (15 January 2011).

HANSEN P. 1996. Silica-scaled Chrysophyceae and Synurophyceae from Madagascar. Archiv für Protistenkunde 147: 145172 .
Huber-Pestalozzi G. 1941. Das Phytoplankton des Süsswassers. 2,1. Chrysophyceen, farblose Flagellaten, Heterokonten. In: Die Binnengewässer (Ed. by A. Thienemann), Band XVI. Schweizerbart'sche Verlagsbuchhandlung, Stuttgart. 365 pp.

Index Nominum Algarum. Index Nominum Algarum, University Herbarium, University of California, Berkeley. Compiled by Paul Silva. Available at: http://ucjeps.berkeley.edu/INA.html (15 January 2011).

IKÄVALKO J. 1994. Contribution to the flora of silica-scaled flagellates in Mikkeli, central Finland. Nova Hedwigia 58: 475-505.

JACOBSEN B.A. 1985. Scale-bearing Chrysophyceae (Mallomonadaceae and Paraphysomonadaceae) from West Greenland. Nordic Journal of Botany 5: 381-398.

Kies L. \& Berndt H. 1984. Die Synura-Arten (Chrysophyceae) Hamburgs und seiner nordöstlichen Umgebung. Mitteilungen aus dem Institut für Allgemeine Botanik Hamburg 19: 99-122.

KIss I. 1978. Occurrence of Synura uvella Ehr. var. tiszaensis n. var. in the dead arm of the river Tisza near Lakitelek. Tiscia 13: 49-54.

Kisselev J.A. 1931. Zur Morphologie einiger neuer und seltener Vertreter des pflanzlichen Mikroplanktons. Archiv für Protistenkunde 73: 235-250.

KLING H.J. \& KRISTIANSEN J. 1983. Scale-bearing Chrysophyceae (Mallomonadaceae) from Central and Northern Canada. Nordic Journal of Botany 3: 269-290.

Korshikov A.A. 1927. Skadovskiella sphagnicola, a new colonial chrysomonad. Archiv für Protistenkunde 58: 450-455.

Korshikov A.A. 1929. Studies on the Chrysomonads. I. Archiv für Protistenkunde 67: 253-290.

Korshikov A.A. 1942. On some new or little known flagellates. Archiv für Protistenkunde 95: 22-44.

KRISTIANSEN J. 1975. Chrysophyceae from Alberta and British Columbia. Syesis 8: 97-108.

KristiansEN J. 1980. Chrysophyceae from some Greek lakes. Nova Hedwigia 33: 167-194.

KRISTIANSEN J. 1988. Seasonal occurrence of silica-scaled chrysophytes under eutrophic conditions. Hydrobiologia 161: 171-184.

Kristiansen J. 1992. Silica-scaled chrysophytes from West Greenland: Disko Island and the Søndre Strømfjord region. Nordic Journal of Botany 12: 525-536.

KRISTIANSEN J. \& LiND J.F. 1995. On the taxonomic relation between Synura curtispina and S. favus (Synurophyceae). Nordic Journal of Botany 15: 443-447.

Kristiansen J. \& Menezes M. 1998. Silica-scaled Chrysophytes from an Amazonian flood-plain lake, Mussurá Lake, northern Brazil. Archiv für Hydrobiologie, Supplement 125 / Algological Studies 90: 97-118.

Kristiansen J. \& Preisig H.R. 2007. Chrysophyte and Haptophyte Algae, 2: Teil/Part 2: Synurophyceae. In: Süsswasserflora von Mitteleuropa (Ed. by B. Büdel, G. Gärtner, L. Krienitz, H.R. Preisig \& M. Schagerl), vol. 1/2. Springer-Verlag, Berlin, Heidelberg. 252 pp.

Kristiansen J. \& Tong D. 1989. Studies on silica-scaled chrysophytes from Wuhan, Hangzhou and Beijing, P.R. China. Nova Hedwigia 49: 183-202.

Kristiansen J. \& Vigna M.S. 2002. Chrysophyceae y Synurophyceae de Tierra del Fuego (Argentina). Monografias del Museo Argentino de Ciencias Naturales 3: 1-45.

Kristiansen J., TONG D. \& OlriK K. 1990. Silica-scaled chrysophytes from Korea, a preliminary study. Nordic Journal of Botany 9: 685-691.

Kristiansen J., Düvel L. \& Wegeberg S. 1997. Silica-scaled chrysophytes from the Taymyr Peninsula, Northern Siberia. Nova Hedwigia 65: 337-351.

Kumar S., Dudley J., Nei M. \& Tamura K. 2008. MEGA: a biologist-centric software for evolutionary analysis of DNA and protein sequences. Briefings in Bioinformatics 9: 299-306.

KYNČLOVÁ A., ŠKAlOud, P. \& ŠKAlOudOvÁ, M. 2010. Unveiling hidden diversity in the Synura petersenii species complex (Synurophyceae, Heterokontophyta). Nova Hedwigia, Beiheft 136: 283-298

Lemmermann E. 1899. Das Phytoplankton sächsischer Teiche. Forschungsberichte aus der Biologischen Station zu Plön 7: 96-135. 
Lemmermann E. 1904. Das Plankton schwedischer Gewässer. Arkiv för Botanik, Uppsala 2: 1-209.

MANTON I. 1955. Observations with the electron microscope on Synura caroliniana Whitford. Proceedings of the Leeds Philosophical and Literary Society 6: 306-316.

Martin-Wagenmann B. \& Gutowski A. 1995. Scale morphology and growth characteristics of clones of Synura petersenii (Synurophyceae) at different temperatures. In: Chrysophyte algae. Ecology, phylogeny and development (Ed. by C.D. Sandgren, J.P. Smol \& J. Kristiansen), pp. 345-360. Cambridge University Press, Cambridge, UK.

NĚMcová Y., Nováková S. \& ŘEzÁČovÁ-ŠKaloudovÁ, M. 2008. Synura obesa sp. nov. (Synurophyceae) and other silica-scaled chrysophytes from Abisko (Swedish Lapland). Nova Hedwigia 86: $243-254$.

Němcová Y., Neustupa J., Kvíderová J. \& ŘezáčováŠKALOUdOVÁ, M. 2010. Morphological plasticity of silica scales of Synura echinulata (Synurophyceae) in crossed gradients of light and temperature - a geometric morphometric approach. Nova Hedwigia, Beiheft 136: 21-32.

Nicholls K.H. \& Gerrath J.F. 1985. The taxonomy of Synura (Chrysophyceae) in Ontario with special reference to taste and odour in water supplies. Canadian Journal of Botany 63: 1482-1493.

NyGAARD G. 1949. Hydrobiological studies on some Danish ponds and lakes. Kongelige Danske Videnskabernes Selskab, Biologiske Skrifter 7: 1-293.

NyGAARD G. 1978. Freshwater phytoplankton from the Narssaq area, South Greenland. Botanisk Tidsskrift 73: 191-238.

Nylander J.A.A. 2004. MrModeltest v2. Program distributed by the author. Evolutionary Biology Centre, Uppsala University, Available at: http://www.abc.se/ nylander/.

PASCHER A. 1908. Ein kleiner Beitrag zur Kenntnis der Chrysomonadinen Böhmens Lotos 57: 148-154.

PAscher A. 1910. Der Grossteich bei Hirschberg in Nord-Böhmen. I. Chrysomonaden. Monographien und Abhandlungen zur Internationale Revue der gesamten Hydrobiologie und Hydrographie 1: 1-66.

PAscher A. 1913. Chrysomonadinae. In: Die Süsswasser-Flora Deutschlands, Oesterreichs und der Schweiz (Ed. by A. Pascher), Vol. 2. G. Fischer, Jena. 7-95 pp.

PÉTERFI L.S. 1965. Observations on Synura Ehrenb. in Rumania with special attention to Synura splendida Korshik. Revue Algologique, 1st ser. 8: 52-55.

Péterfi L.S. 1967. Studies on the Rumanian Chrysophyceae. I. Nova Hedwigia 13: 117-137.

Péterfi L.S. \& Momeu L. 1977. Remarks on the taxonomy of some Synura species based on the fine structure of scales. Studii si comunicari Muzeul Brukenthal Stiinte Naturale 21: 15-23.

Petersen J.B. 1918. Om Synura uvella Stein og nogle andre Chrysomonadiner. Videnskabelige Meddelelser Fra Dansk Naturhistorisk Forening 69: 345-357.

Petersen J.B. \& Hansen J.B. 1956. On the scales of some Synura species. Biologiske Meddelelser, Kongelige Danske Videnskabernes Selskab 23, (2), 3-27.

Petersen J.B. \& Hansen J.B. 1958. On the scales of some Synura species. II. Biologiske Meddelelser, Kongelige Danske Videnskabernes Selskab 23, (7), 1-13.

Philipose M.T. 1953. Contribution to our knowledge of Indian algae. I. Chrysophyceae. Proceedings of the Indian Academy of Sciences B 37: 331-338.

Playfair G.I. 1915. Freshwater algae of the Lismore District: with an appendix on the algal fungi and Schizomycetes. Proceedings of the Linnean Society of New South Wales 40: 310-362.

Playfair G.I. 1921. Australian freshwater flagellates. Proceedings of the Linnean Society of New South Wales 46: 99-146.

PRÖSChOld T. \& Leliaert F. 2007. Systematics of the green algae: conflict of classic and modern approaches. In: Unravelling the algae: the past, present, and future of the algae (Ed. by J. Brodie \& J. Lewis), pp. 123-153. Taylor and Francis, London.

Ronquist F. \& Huelsenbeck J.P. 2003. MRBAYES 3: Bayesian phylogenetic inference under mixed models. Bioinformatics 19: 1572-1574.

ŘEZÁČOvÁ M. \& ŠKALOUd, P. 2005. Silica-scaled chrysophytes of Ireland. With an appendix: Geographic variation of scale shape of Mallomonas caudata. Nova Hedwigia, Beiheft 128: 101-124.
ŘEZÁČOvÁ-ŠKaloudovÁ M., Neustupa J. \& NĚMcovÁ Y. 2010 Effect of temperature on the variability of silicate structures in Mallomonas kalinae and Synura curtispina (Synurophyceae). Nova Hedwigia, Beiheft 136: 55-70.

SANDGRen C.D., Hall S.A. \& Barlow B.S. 1996. Siliceous scale production in chrysophyte and synurophyte algae. I. Effects of silica-limited growth on cell silica content, scale morphology, and the construction of the scale layer of Synura petersenii cells. Journal of Phycology 32: 675-692.

SChILler J. 1929. Neue Chryso- und Chryptomonaden aus Altwässern der Donau bei Wien. Archiv für Protistenkunde 66: 436- 458.

Siver P.A. 1987. The distribution and variation of Synura species (Chrysophyceae) in Connecticut, USA. Nordic Journal of Botany 7: 107-116.

Siver P.A. 1988. A new form of the common chrysophycean alga Synura petersenii. Transactions of the American Microscopy Society 107: 380-385.

Siver P.A. \& LotT A.M. 2004. Further observations on the scaled Chrysophycean and Synurophycean flora of the Ocala National Forest, Florida, U.S.A. Nordic Journal of Botany 24: 211-233.

Siver P.A. \& Wolfe A.P. 2005. Scaled chrysophytes in middle Eocene lake sediments from northwestern Canada, including descriptions of six new species. Nova Hedwigia, Beiheft 128: 295-308.

Siver P.A. \& WUJEK D.E. 1993. Scaled Chrysophyceae and Synurophyceae from Florida, USA. IV. The flora of Lower Lake Myakka and Lake Tarpon. Florida Scientist 56: 109-117.

Siver P.A. \& WuJeK D.E. 1999. Scaled Chrysophyceae and Synurophyceae from Florida, USA. VI. Observations on the flora from water bodies in the Ocala National Forest. Nova Hedwigia 68: 75-92.

Siver P.A., Voloshko L.N., Gavrilova O.V. \& Getsen M.V. 2005. The scaled chrysophyte flora of the Bolshezemelskaya tundra (Russia). Nova Hedwigia, Beiheft 128: 125-149.

Skuja H. 1956. Taxonomische und biologische Studien über das Phytoplankton schwedischer binnengewässer. Nova Acta Regiae Societatis Scientiarum Upsaliensis, Series 4 16: 1-404.

Skvortsov B.V. 1958. New and rare Flagellatae from Manchuria, Eastern Asia. Philippine Journal of Science 86: 139-202.

Skvortsov B.V. 1961. Harbin Chrysophyta, China borealiorientalis. Bulletin of the Herbarium of North-Eastern Forestry Academy 3: 1-70.

Sмith G.M. 1924. Ecology of the plankton algae in Palisades Interstate Park, including the relation of control methods to fish culture. Roosevelt Wild Life Bulletin 2: 95-195.

StARmach K. 1968. Chrysophyta I. Chrysophyceae-Zlotowiciowce. Flora Slodkowodna Polski 5: 1-598.

STEINECKe F. 1968. Die Algen des Zehlaubruches in systematischer und biologischer Hinsicht. Schriften der koniglichen physikalischokonomischen Gesellschaft zu Konigsberg 56: 1-138.

STEINECKe F. 1922. Die Algen des Pakledimmer Hochmoors. Botanisches Archiv 1: 225-229.

SwOFFORD D.L. 2002. PAUP*. Phylogenetic Analysis Using Parsimony (*and Other Methods). Version 4. Sinauer Associates, Sunderland, MA.

TAKahashi E. 1967. Studies on genera Mallomonas, Synura and other plankton in freshwater with the electron microscope. VI. Morphological and ecological observations on genus Synura in ponds and lakes in Yamagata Prefecture. Bulletin of the Yamagata University. Agricultural Science 5, 2: 99-118 [199-218].

TAKAhashi E. 1972. Studies on genera Mallomonas and Synura, and other plankton in freshwater with electron microscope. VIII On three new species of Chrysophyceae. Botanical Magazine Tokyo 85: 293-302.

VignA M.S. 1979. Ultraestructura de las escamas de Synura petersenii Korsh. f. bonaerensis nov. forma (Ochromonadales). Boletín de la Sociedad Argentina de Botánica 18: 47-51.

Vigna M.S. \& MunARi C. 2001. Seasonal occurrence of silicascales chrysophytes in a Buenos Aires lake. Nova Hedwigia, Beiheft 122: 195-209.

ViRIEUX J. 1916. Recherches sur le plancton des lacs du Jura central. Annales de Biologie Lacustre 8: 1-192. 
WeE J.L. 1981. Studies on silica-scaled chrysophytes from Iowa. II. Common Synura species. Proceedings of the Iowa Academy of Science 88: 70-73.

Wee J.L., Fasone L.D., Sattler A., Starks W.W. \& Hurley D.L. 2001. ITS/5.8S DNA sequence variation in 15 isolates of Synura petersenii Korshikov (Synurophyceae). Nova Hedwigia, Beiheft 122: 245-258.

Whitford L.A. 1943. The fresh-water algae of North Carolina. Journal of the Elisha Mitchell Scientific Society 59: 131-170.

WUJeK D.E. \& CARTER S.A. 2002. Identification, ecology and distribution of silica-scaled chrysophytes from the Carolinas. II. Mountain Region. Journal of the North Carolina Academy of Science 118: 137-144.

WujeK D. \& ElSNer P. 2000. Synura longisquama, sp. nov., a new synurophyte from South Carolina. Journal of the Elisha Mitchell Scientific Society 116: 97-100.

Wujek D.E. \& O'Kelly, C. 1992. Silica-scaled Chrysophyceae (Mallomonadaceae and Paraphysomonadaceae) from New Zealand freshwaters. New Zealand Journal of Botany 30: 405-414.
Wujek D.E. \& Thompson R.H. 2001. The chrysophyte genera Synuropsis Schiller, Volvochrysis Schiller, Synochromonas Korshikov, Pseudosynura Kisselew, Pseudosyncrypta Kisselew, Chrysomoron Skuja, and Syncrypta Ehrenberg. Transactions of the Kansas Academy of Science 104: 79-91.

WuJek D.E. \& VAN DER VeER J. 1976. Scaled chrysophytes from The Netherlands including a description of a new variety. Acta Botanica Neerlandica 25: 179-190.

ZaChARIAs O. 1987. Neue Beiträge Kenntnis des Süsswasserplanktons. Forschungsberichte aus der Biologischen Station zu Plön 5: $1-9$.

ZwICKL D.J. 2006. Genetic algorithm approaches for the phylogenetic analysis of large biological sequence datasets under the maximum likelihood criterion. $\mathrm{PhD}$ dissertation, University of Texas at Austin, Austin.

Received 9 February 2011; accepted 15 September 2011 Associate editor: Øjvind Moestrup 